TO ENGAGE OR NOT TO ENGAGE WITH HOST GOVERNMENTS: CORPORATE POLITICAL ACTIVITY AND HOST-COUNTRY POLITICAL RISK

\author{
Authors \\ Maria A. De Villa, Professor of Strategy (Corresponding Author) \\ Alta Dirección, School of Management, Universidad EAFIT \\ Cra 49 No 7sur 50, Medellin 3300 \\ Colombia (South America) \\ Phone: +57 (4) 2619500 extension 9778 \\ e-mail: mdevilla@eafit.edu.co \\ Tazeeb Rajwani, Professor of International Business and Strategy \\ Essex Business School, University of Essex \\ Elmer Approach, Southend-on-Sea SS1 1LK \\ United Kingdom \\ Phone: +44 (0) 1702328439 \\ e-mail: tazeeb.rajwani@essex.ac.uk
}

Thomas C. Lawton, Professor of Strategy and International Business

Surrey Business School

University of Surrey, Guildford, Surrey GU2 7XH

United Kingdom

Phone: +44 (0) 1483686300

e-mail: thomas.lawton@surrey.ac.uk

Visiting Professor of Business Administration

Tuck School of Business at Dartmouth

Hanover, New Hampshire 03755

United States

Phone: +1 6036461859

e-mail: thomas.c.lawton@tuck.dartmouth.edu

Kamel Mellahi, Professor of Strategic Management

Warwick Business School

The University of Warwick, Coventry CV4 7AL

United Kingdom

Phone: +44 (0) 2476151393

e-mail: kamel.mellahi@wbs.ac.uk

This article has been accepted for publication.

This article is protected by copyright. All rights reserved. 


\begin{abstract}
Research summary: We analyze how a host market's institutional context can influence an MNE's senior management's choice and deployment of corporate political activity (CPA). First, we argue that a non-engaged approach to CPA is likely to be chosen when senior management perceives high hostcountry political risk, arising not only from host-country political institutions, but also from the distance between home and host-government relations. Second, we propose that the deployment of this approach can require active adaptation through four political strategies: low-visibility, ensuring a minimal degree of general attention from other actors; rapid-compliance, entailing high speed actions to obey the rules; reconfiguration, involving re-arranging the MNE's structure and processes for competitiveness; and anticipation, implying the prediction of public policy and analysis of interest groups to anticipate responses.
\end{abstract}

Managerial summary: Senior managers of multinational enterprises (MNEs) often examine when and how to engage, or not to engage, with host governments. We argue that senior managers are likely to choose to evade engagement with a host government when they perceive high host-country political risk, not only through public political risk ratings, but also via their home and host-government relations. We show that this choice can require senior managers to lead active adaptation through four strategies: low-visibility, enabling the MNE to operate under the radar of host governments; rapidcompliance, entailing high speed actions to obey the rules; reconfiguration, involving re-arranging the MNE's structure and processes for competitiveness; and anticipation, implying the prediction of public policy and analysis of interest groups to anticipate responses.

KEYWORDS: corporate political activity; political risk; home and host-government relations; adaptation; political strategies 


\section{TO ENGAGE OR NOT TO ENGAGE WITH HOST GOVERNMENTS: CORPORATE POLITICAL ACTIVITY AND HOST-COUNTRY POLITICAL RISK}

\section{INTRODUCTION}

Corporate political activity (CPA) research focuses on firms' engaging with government to influence public policy in ways favorable to their corporate interests (Hillman, Keim, and Schuler, 2004). In contrast, neo-institutional theory has concentrated on firms not engaging with government, but rather, passively conforming to institutional pressures (Scott, 2014). Yet, few studies have kept pace with multinational enterprises' (MNEs') cross-border CPA choices (Blumentritt, 2003; Kobrin, 2015). These choices ultimately dichotomize into, first, an engaged approach to CPA, that involves engaging with host governments to influence host-country public policy, and second, a non-engaged approach to CPA, that involves not engaging with host governments but rather, avoiding or conforming to hostcountry public policy.

Building on the notion that a global approach to MNE CPA is unlikely to be successful (Baron, 1995; Blumentritt, 2003; Kobrin, 2015), we argue that that both CPA research and neoinstitutional theory remain unclear as to how the institutional context of a host market can influence an MNE's senior management's choice of when to deploy an engaged or a non-engaged approach to CPA. We address this gap to explore how the institutional context of a host market can influence when an MNE's senior management chooses a non-engaged approach to CPA, and examine how this approach is deployed. We aim to answer two research questions. First, how can the institutional context of a host market influence when an MNE's senior management chooses a non-engaged approach to CPA? Second, how does an MNE deploy a non-engaged approach to CPA in host markets?

We focus on a non-engaged approach to CPA for two reasons. First, from a neo-institutional perspective, theoretical arguments explain that a non-engaged approach to CPA can be a deliberate choice when the institutional context offers high levels of environmental uncertainty (Oliver, 1991). Whereas CPA literature explains that a non-engaged approach to CPA can be caused by, the nonnecessity of engaging due to the favorability of government policy toward the interests of the firm; 
restrictive regulatory conditions that impede a firm from participating in government affairs; or a firm's inability to engage based on its relative lack of political resources and capabilities (Boddewyn and Brewer, 1994; Bonardi, Holburn, and Vanden Bergh, 2006; Holburn and Zelner, 2010). Overall, our core contention with extant literature is that we require further institutional-based explanations of the deliberate choice of a non-engaged approach to CPA, particularly, that originate in host markets and from empirical evidence. Second, how MNEs deploy a non-engaged approach to CPA in host markets has been underexplored. Neo-institutional theorists argue that a non-engaged approach to CPA can be deployed by the strategies of avoidance or acquiescence (Oliver, 1991; Scott, 2014). While CPA literature has theoretically conceptualized non-engaged political strategies that are lacking empirical support (Boddewyn and Brewer, 1994; Oliver and Holzinger, 2008). Thus, to improve our understanding of how a non-engaged approach to CPA can be deployed by MNEs in host markets, we argue that further empirical evidence is required.

To answer our research questions, we used an inductive case study that tracked the CPA choices deployed over sixteen years by Nutresa, a large Colombian MNE, in its five primary host markets: the United States, Costa Rica, Venezuela, Ecuador, and Nicaragua. Nutresa leads the food business of one of the most powerful business groups in Colombia, the Grupo Empresarial Antioqueño (GEA). In 2015, the GEA generated an income of USD $\$ 50$ billion, which accounted for more than 5 percent of Colombia's GDP (Dinero, 2016). We selected Nutresa because, despite identifying opportunities to improve the favorability of host-government policies and regulatory conditions allowing its participation in host-government affairs, and although it possessed the political resources and capabilities required to engage with host governments, Nutresa deliberately chose and deployed a non-engaged approach to CPA in some of its primary host markets.

Our study makes three contributions to the extant literature. First, building on neo-institutional theory (DiMaggio, 1988; Oliver, 1991; Scott, 2014) and drawing on political economy (Hirschman, 1970), we identify that when an MNE's senior management perceives high host-country political risk, it is more likely to choose a non-engaged approach to CPA in the host market. Thus, we extend the literatures on neo-institutional theory (DiMaggio, 1988; Oliver, 1991; Scott, 2014) and the antecedents of CPA choices (for reviews on antecedents of CPA see Hillman et al., 2004 and Lux, Crook, and 
Woehr, 2011) by theoretically classifying and explaining an MNE's senior management's perceived host-country political risk as an antecedent of MNE CPA choices in host markets. Moreover, we explain how the influence of perceived host-country political risk is moderated not only by risk arising from host-country political institutions (Henisz, 2000; Stevens, Xie, and Peng, 2016), but also by risk emanating from the distance between an MNE's home and host-government relations (Blumentritt and Nigh, 2002; Ghemawat, 2001). We argue that despite the level of risk arising from host-country political institutions, a high level of distance between an MNE's home and host-government relations is likely to increase an MNE's senior management's perceived host-country political risk.

Consequently, senior management is more likely to choose a non-engaged approach to CPA in the host market.

Second, we develop a nuanced conceptualization of approaches to CPA that challenges the notion that not engaging with government only involves avoiding or passively conforming to institutional pressures (Oliver, 1991; Scott, 2014). In contrast, we explain that when an MNE's senior management perceives high host-country political risk, it is more likely to choose a non-engaged approach to CPA that involves either avoiding or actively adapting to host-country public policy. We detail how actively adapting to host-country public policy can be deployed through four legal nonengaged political strategies. These are: low-visibility strategy, that ensures a minimal degree of general attention from political and social actors; rapid-compliance strategy, that entails high speed actions to obey the rules; reconfiguration strategy, that involves re-arranging the MNE's organizational structure and processes for competitiveness; and anticipation strategy, that implies the prediction of public policy and analysis of interest groups to anticipate responses. In so doing, we develop a taxonomy of legal non-engaged political strategies that improves our understanding of how a non-engaged approach to CPA can be deployed (Boddewyn and Brewer, 1994; Oliver, 1991; Oliver and Holzinger, 2008; Shafer, 1995).

Third, our study contributes to a growing strand of literature focused on the analysis of emerging market MNEs, as Nutresa is an emerging market MNE from Latin America. This strand of literature suggests that several unique characteristics of Latin American countries, such as political uncertainty, make multilatinas a research laboratory with potential for extending not only the 
understanding of these firms but also, and more importantly, the understanding of theories and models that explain the behavior of MNEs (Cuervo-Cazurra, 2016). In the case of Nutresa, its country of origin proved a challenge to expanding operations into some high political risk emerging economies in Latin America. This enabled Nutresa to develop expertise in managing high political risk in host markets in different ways (Cuervo-Cazurra and Genc, 2008). Such experience is relevant to all MNEs, as it can become a source of advantage, not only in managing operations in host markets with high political risk, but also in managing the diversity of institutional contexts across host markets to internationalize more widely (Cuervo-Cazurra, 2016). Hence, through a fine-grained analysis of this special and revelatory case, we extend our understanding of multinationals' corporate political behavior in various institutional contexts (Cuervo-Cazurra, 2016; Cuervo-Cazurra et al., 2016).

Taken together, these contributions offer, first, a framework that explains the influence of perceived host-country political risk on MNE CPA choices in host markets, and second, a taxonomy of legal non-engaged political strategies to stay in or enter host markets of high political risk. Both, constitute what Hafsi and Thomas (2005) refer to as walking sticks to assist MNEs' senior management in their CPA decision-making processes. Yet, the most important implication of this study for management practice is to shed light on an underexplored option available when perceiving high host-country political risk - the option of loyalty. This option implies staying in or entering a host market by not engaging with its host government, but rather, actively adapting to host-country public policy through legal non-engaged political strategies. In contrast, when confronting challenging hostcountry conditions, most previous studies discuss the option to exit (Meyer et al., 2009; Rodriguez, Uhlenbruck, and Eden, 2005).

\section{THEORETICAL BACKGROUND}

\section{Approaches to CPA and political strategies}

We define corporate political activity as corporate attempts to manage government policy through an engaged or a non-engaged approach. Extant research has focused on an engaged approach to CPA, enabling an MNE to influence host-country public policy by engaging with the host government (Baysinger, 1984; Hillman et al., 2004; Lawton, McGuire, Rajwani, 2013). This approach can allow an MNE to have greater power to exert influence over host-country public policy, the greater its 
engagement with the host government or embeddedness in host-government affairs (Heidenreich, 2012; Kostova, Roth, and Dancin, 2008; Oliver and Holzinger, 2008). To deploy an engaged approach to CPA, a large body of research discusses several taxonomies that list and describe the engaged political strategies that can be used (Aplin and Hegarty, 1980; Baysinger, 1984; Boddewyn and Brewer, 1994; Bonardi, Hillman, and Keim, 2005; Getz, 1993; Hillman and Hitt, 1999; Hillman et al., 2004; Oberman, 1993; Oliver, 1991; Oliver and Holzinger, 2008). The three generic engaged political strategies—information, financial incentive, and constituency-building—conceptualized by Hillman and Hitt (1999) drawing on exchange theory, have become the most cited. Examples of the tactics used to deploy these engaged political strategies include lobbying host-government decision makers by providing information about the potential impact of possible legislation, making financial campaign contributions, and expressing support for a political party through advocacy advertising (see Hillman and Hitt, 1999).

On the other hand, a non-engaged approach to CPA has the aim of enabling an MNE to avoid or conform to host-country public policy by evading engagement with the host government or exercising disembeddedness from host-government affairs (Heidenreich, 2012; Scott, 2014). From a neo-institutional perspective, avoiding host-country public policy can be achieved by the strategy of avoidance while conforming to host-country public policy can be enabled by the strategy of acquiescence (Oliver, 1991). Examples of the tactics used to deploy these two non-engaged political strategies include avoiding operations in the host market and complying with host-country public policy without aiming to shape or modify its contents. In contrast to neo-institutional theory, CPA research has provided less attention to a non-engaged approach to CPA. Nonetheless, four distinctive non-engaged political strategies that have been theoretically conceptualized in this strand of literature, however lacking empirical support, are: avoidance, compliance, circumvention (see Boddewyn and Brewer, 1994), and anticipatory (see Oliver and Holzinger, 2008). Examples of the tactics used to deploy these non-engaged political strategies, include again, avoiding operations in the host market and complying with host-country public policy without aiming to shape or modify its contents. Also, undertaking circumvention or illegal activities such as trade smuggling and anticipating potential changes in host-country public policy to design early compliance mechanisms. 
It is worth noting that both an engaged and a non-engaged approach to CPA involve MNEs' compliance with host-country public policy. However, under an engaged approach to CPA, MNEs comply with host-country public policy as they search to shape or modify its contents in ways favorable to their corporate interests. Whereas under a non-engaged approach to CPA, MNEs comply with host-country public policy without aiming to shape or modify its contents (see Table 1).

\section{Insert Table 1 Here}

\section{Antecedents of CPA choices}

Among the antecedents that can influence an MNE's senior management's choice of when to deploy an engaged or a non-engaged approach to CPA in host markets are firm, industry, issue-specific, and institutional factors (Hillman et al., 2004 and Lux et al., 2011). Most CPA studies focus on how these factors influence when an engaged approach to CPA is chosen. These studies have found that an engaged approach to CPA is likely to be chosen when firms achieve a sufficient size to enable the development of political resources and capabilities to engage with government (Boddewyn and Brewer, 1994; Keim and Baysinger, 1988; Masters and Keim, 1985), belong to a highly regulated industry (Evans, 1988; Grier and Munger, 1993), view a specific political issue as important (Schuler and Rehbein, 1997; Vogel, 1996), or find that collective goods are missing in the institutional context and therefore engage with government to collaborate in their creation (Boddewyn and Doh, 2011). Beyond the findings of these individual studies, a meta-analysis identified the primary antecedents that can influence the choice of an engaged approach to CPA as firm size, level of government regulation, and a politician's ability to deliver demanded policy (Lux et al., 2011). In addition, from a neoinstitutional perspective, theoretical arguments suggest that an MNE is more likely to choose an engaged approach to CPA, the lower the level of environmental uncertainty in the institutional context (Oliver, 1991).

In contrast, scarce attention has focused on the factors that can influence when a non-engaged approach to CPA is chosen. Prior CPA research explains that the choice of a non-engaged approach to CPA is often perceived as caused by, the non-necessity of engaging due to the favorability of government policy toward the interests of the firm; restrictive regulatory conditions that impede a firm from participating in government affairs; or a firm's inability to engage based on its relative lack of 
political resources and capabilities (Boddewyn and Brewer, 1994; Bonardi et al., 2006; Holburn and Zelner, 2010). While from a neo-institutional perspective, theoretical arguments suggest that a nonengaged approach to CPA can be a deliberate choice when the institutional context offers high levels of environmental uncertainty (Oliver, 1991).

To advance our understanding of the antecedents of CPA choices, extant literature suggests that future research can build on empirical work (Lux et al., 2011). We aim to respond to this call by using empirical evidence to show how the institutional context of a host market can influence MNE CPA choices, particularly, the choice of a non-engaged approach to CPA.

\section{MNE CPA choices in host markets}

We build on neo-institutional theory (DiMaggio, 1988; Oliver, 1991; Scott, 2014) and draw on political economy using Hirschman's (1970) exit, voice, and loyalty framework, to explore MNE CPA choices in host markets. Early neo-institutional theory neglected the view of a non-engaged approach to CPA as a deliberate choice (DiMaggio and Powell, 1983; Meyer and Rowan, 1977; Meyer and Scott, 1983). Power was attributed to the institutional context, while firms were regarded as passive victims of institutional pressures (DiMaggio and Powell, 1983; Scott, 2014). This perspective raised criticisms for its assumptions of organizational passivity and its failure to address organizational selfinterests and active agency in firms' direct responses to the institutional context (DiMaggio, 1988; Perrow, 1985; Powell, 1985). Consequently, subsequent research recognized that firms not only have the power to choose their direct responses to the institutional context, but also to respond in diverse ways, ranging from passively conforming to exerting influence over institutional pressures (Oliver, 1991; Scott, 2014). Under this view, theoretical arguments claimed that a non-engaged approach to CPA can be a deliberate choice when the institutional context offers high levels of environmental uncertainty (Oliver, 1991).

Despite neo-institutional theorists recognizing that firms have the power to choose their direct responses to the institutional context, government continued to be viewed as relying on the power of legitimate coercion or the ability to exercise authority over firms (DiMaggio and Powell, 1983; Scott, 2014; Streeck and Schmitter, 1985). As an example, neo-institutional theorists explain that legal or government mandates are imposed over firms by means of authority rather than through pressures for 
their voluntary compliance (Scott, 2014). Thus, firm and government relations are perceived as a cost or an institutional constraint on firms (DiMaggio and Powell, 1983; Scott, 2014). Neo-institutional theorists argue that firms depend on government as it can change the rules of the game that allow their existence and operations and has the power to expropriate firm assets (Scott, 2014). Such unavoidable dependence of firms on government, increases firms' likelihood or need to comply with public policy (DiMaggio and Powell, 1983; Oliver, 1991).

Beyond government, neo-institutional theorists also view interest groups and the public opinion as part of the institutional context that exerts pressures on firms to conform to their requirements (Scott, 2014). To ensure legitimacy, firms need to gain acceptability and credibility from these wider stakeholders. Neo-institutional theorists argue that firms exhibiting culturally approved forms and activities, receiving support from normative authorities, and having approval from legal bodies, are more likely to survive due to their social fitness or perceived appropriateness, than firms lacking these evaluations (Deephouse et al., 2017; Meyer and Rowman, 1977). Therefore, conformity is viewed as useful to firms in terms of enhancing their likelihood of survival through a variety of rewards, such as increased prestige, legitimacy, and social support (DiMaggio, 1988; DiMaggio and Powell, 1983; Meyer and Rowman, 1977). Moreover, neo-institutional theorists have demonstrated that legitimacy and social support can exert influence on a firm's viability, independent of its performance, or can even confer performance advantages to firms (Bansal and Roth, 2000; Baum and Oliver, 1991; Deephouse, 1996; Suchman, 1995).

Altogether, on the one hand, neo-institutional theory has recognized that firms have the power to choose their direct responses to the institutional context. While on the other hand, government along interest groups and the public opinion are viewed as stakeholders that can exert institutional pressures on firms to conform to their requirements. Consequently, as firms expand the scope of their operations to various institutional contexts and become MNEs, their senior management often examines when and how to choose and deploy an engaged or a non-engaged approach to CPA in each host market. The aim of any of these approaches to CPA is to enable the viability of the MNE's existence and operations, or even to confer performance advantages. To analyze this choice, we draw on Hirschman's (1970) exit, voice, and loyalty framework to explain how the institutional context of a 
host market can influence an MNE's senior management to decide upon three options. These options entail choosing and deploying an engaged or a non-engaged approach to CPA as a direct response to the institutional context.

The first option in Hirschman's (1970) framework, is the option to exit. This option implies leaving or not entering a host market (Meyer et al., 2009; Rodriguez et al., 2005). To exercise exit, an MNE's senior management chooses a non-engaged approach to CPA to evade engagement with the host government and disembed from host-government affairs (Heidenreich, 2012). This approach is deployed through the non-engaged political strategy of avoidance by avoiding operations in the host market. Thus, under exit, an MNE's senior management neglects its right to have voice as the result of being either unable or unwilling to invest in efforts to influence host-country public policy (Boddewyn and Brewer, 1994). In contrast, the second option available to MNEs is to exert influence through voice, this implies staying in or entering a host market. To exercise voice, an MNE's senior management chooses an engaged approach to CPA and deploys any combination of Hillman and Hitt's (1999) engaged political strategies with the aim of shaping or modifying host-country public policy in ways favorable to its corporate interests. In doing so, an MNE engages with the host government and works on embedding itself in host-government affairs to have greater power to exert influence over host-country public policy.

Hirschman's (1970) options of exit and voice present a dichotomy. Whereas the third option available to MNEs, the option of loyalty, can affect the cost-benefit analysis of whether to choose exit or voice. The option of loyalty involves no exit and no voice, it implies staying in or entering a host market without exerting influence over host-country public policy. To exercise loyalty, since this option involves no voice, an MNE's senior management chooses and deploys a non-engaged approach to CPA. The options of exit and loyalty both entail choosing a non-engaged approach to CPA, however, their key difference is that exit implies leaving or not entering a host market while loyalty implies staying in or entering a host market.

Overall, extant CPA research has focused on an engaged approach to CPA to exercise the option of voice by staying in or entering a host market (Hillman and Hitt, 1999; Rodriguez et al., 2006). Nonetheless, when confronting challenging host-country conditions, most previous studies 
discuss the option to exit that involves leaving or not entering a host market by deploying a nonengaged approach to CPA (Meyer et al., 2009; Rodriguez et al., 2005). Yet, other scholars argue that when an MNE's senior management chooses to stay in or enter a host market, they may need to consider flying under the radar by evading engaged political strategies because engaging with the host government can increase an MNE's visibility and risk exposure (Puck, Rogers, and Mohr, 2013). Despite this notion resonating with the option of loyalty, the question remains as to how can the institutional context of a host market influence when and how an MNE's senior management chooses and deploys a non-engaged approach to CPA to exercise loyalty. To advance our understanding, the state of extant literature suggests we can build an intimate connection with empirical reality through inductive case study research, to better understand the mechanisms that underlie this approach (Edmondson and McManus, 2007). Thus, we follow this research design, while focusing on a nonengaged approach to CPA deployed through legal non-engaged political strategies. Therefore, circumvention or any illegal political strategies are beyond the scope of this study. Rather, based on empirical insight, we aim to refine our understanding of the acquiescence, compliance, and anticipatory strategies, that have been theoretically conceptualized in prior literature as legal nonengaged political strategies.

\section{METHODS}

\section{Research design}

We used an embedded design in our inductive case study (Eisenhardt, 1989; Yin, 2009) in which within the case of Nutresa, we tracked and contrasted over a sixteen-year timeframe-1998 to 2013this MNE's CPA choices in its five primary host markets: the United States, Costa Rica, Venezuela, Ecuador, and Nicaragua. Through an intimate and iterative connection between data and extant literature, we were interested in inductively developing accurate and parsimonious theory from casebased empirical evidence (Eisenhardt and Graebner, 2007; Huff, 2009; Langley, 1999).

\section{Research context}

Nutresa was formed at the beginning of the 20th century, during Colombia's industrial development. The company's internationalization process began in the 1960's with opportunistic exports. It was not until the 1990's that these exports transformed into deliberate efforts to compete and grow in response 
to economic liberalization. In 1995, Nutresa initiated the creation of wholly-owned distribution operations, and in 1996, the acquisition of production platforms in Latin America and beyond. Nutresa expanded primarily by acquiring companies with well-positioned brands and developed distribution operations. This internationalization process led Nutresa to own production and/or distribution operations in 15 countries on three continents: Latin America, North America, and Asia. Also, Nutresa exported to over 72 countries, reaching Europe, Africa, and Oceania. These achievements enabled Nutresa to be classified in 2007 by America Economia's ranking of multilatinas, as Colombia's most international multinational, and as one of the most important players in its industry in Latin America.

During the timeframe of our study—1998 to 2013—, Nutresa's international scope and sales grew more than in any other period in its prior corporate history. International sales increased from USD $\$ 10.9$ million to USD $\$ 1.1$ billion, corresponding to approximately 4 percent of total sales in 1998 and 34.3 percent of total sales_-USD \$3.2 billion—in 2013. Moreover, its profits multiplied 11fold while employees in host markets grew from 400 to 12,045, reaching a total number of 36,726 employees worldwide. In this timeframe, the United States, Costa Rica, Venezuela, Ecuador, and Nicaragua came to be Nutresa's five primary host markets by accounting for almost 60 percent of international sales and 20 percent of total sales. Insights from interviews with Nutresa's senior managers indicated that, from 1998 to 2013, they had decided to stay in or enter these five primary host markets by choosing, in some cases, to engage, and in other cases, not to engage, with their host governments. They explained that, due to the strategic importance of these host markets, Nutresa dedicated significant time and resources to deliberately choosing and deploying the most customized and effective approach to CPA in each host market. Thus, within Nutresa, the CPA history of its five primary host markets from 1998 to 2013, provided the ideal research context for detailed fieldwork on MNE CPA choices in host markets (Cuervo-Cazurra et al., 2016).

\section{Data collection}

We used several data sources: (1) interviews, with informants from within and outside of Nutresa; (2) documents, including public annual reports, an internal report about the evolution of the number of employees versus sales in each host market, and classified records of the strategic tools developed by Nutresa for its operations in Venezuela; and (3) archives, including public media articles about the 
chronology of events that occurred and Nutresa's corporate political activities in each host market (see Table 2). We relied on interviews as the primary data source, with documents and archives serving as important triangulation and supplementary sources to enhance validity and reliability (Eisenhardt, 1989; Yin, 2009).

\section{Insert Table 2 Here}

The primary data source included 60 in-depth semi-structured interviews that involved informants from different organizational levels, functional areas, and geographies within Nutresa, as well as outsiders such as industry and trade experts. We built our list of informants by, first, using Nutresa's organizational chart and, second, including those who were referred by others as knowledgeable informants through snowball sampling. At the first organizational level, we interviewed board members, the CEO, the Vice-Presidents (VPs) of the business lines with operations in the host markets, the Chief Financial Officer (CFO), and the Vice-President of the General Council. At the second organizational level, we interviewed the General Managers of the operations in the host markets and informants from different functional areas who were located both at headquarters and in the host markets. These included International Business Directors, Logistics Managers, Marketing Directors, and the Coordinators of centralized treasury, auditing, legal assessment, human resources, risk management, innovation, and information technology (IT). At the operational level, we interviewed business level staff from the previously listed functions who were dispersed throughout headquarters and the host markets. Further, we included informants who were outsiders, such as the ex-CEO of a Venezuelan retail chain, the President of Colombia's international trade association, and a former Colombian Ambassador to Venezuela. Overall, we were careful to cover the total population of knowledgeable informants within Nutresa, from the first level to the operational level, to ensure completeness and different hierarchical, functional, and geographical views. These informants had worked for Nutresa for an average of 17 years, providing extensive coverage of the sixteen-year timeframe-1998 to 2013. In addition, a mix of insiders and outsiders ensured our interview data provided both perspectives.

We conducted our interviews by following Hillman and Hitt's (1999) approach whereby our aim was to identify the chronology of political activities deployed by Nutresa in each of its primary 
host markets. Political activities refer to the political tactics that make up the political strategies used by firms. Our purpose was to first, identify the political tactics and strategies deployed by Nutresa to uncover its chosen approaches to CPA and options in each host market. Second, to identify the underlying mechanisms that explained how the institutional context of a host market had influenced Nutresa's senior management's choice of when to deploy a non-engaged approach to CPA. Finally, to explain how Nutresa had deployed this approach to stay in or enter some of its primary host markets.

We began conducting overview interviews, first, with the CEO, and then the board members and all other first level senior management. The aim was to capture a detailed overview of Nutresa's CPA history in each of its primary host markets. We then conducted host market interviews with all other internal informants from within Nutresa. These interviews aimed to add detail and centered on a deeper understanding of the chronology of events that occurred and the political tactics deployed by Nutresa in each host market. We also conducted contextual interviews with outsiders that focused on providing an external view of the chronology of events and Nutresa's CPA.

To limit bias in our interview data, we used data collection approaches for increasing accuracy in retrospective research (Huber and Power; 1985; Golden, 1992; Miller, Cardinal, and Glick, 1997). A key approach was that we motivated the participation of informants by granting anonymity, which encourages candor. To build a realistic data structure, informants were motivated to equally share their positive and negative insights. We engaged with them by conducting face-to-face interviews to establish a closer relationship of trust. We also designed and pre-tested an interview protocol with indepth semi-structured questions and follow-up probes to ensure our questions were understood and answered completely while leaving time for open-ended questioning. Our interviews ranged from 45 to 150 minutes in duration, were recorded and transcribed.

\section{Data analysis}

We followed three steps in our data analysis. The first step involved building individual case chronologies for each of the five primary host markets to create Nutresa's CPA case history and identify its CPA choices. The second and third steps aimed to answer each of the research questions.

The first step began by assembling for each host market a chronology of the events that occurred and the political tactics that Nutresa deployed by cross-matching the interviews with 
documents and public media articles. We began elaborating these chronologies by first identifying in the public media articles the events that occurred and the documented political tactics that Nutresa had exercised vis-à-vis these events. Then, we coded the interviews to better understand these events, the political tactics deployed by Nutresa, and their approach—-to engage, or not to engage, with host governments. Finally, we used the documents to complement our chronologies with additional public and internal firm data. Each of our final chronologies ranged from 10 to 58 pages and presented a longitudinal factual account of the most important events in each host market. This research approach follows Miles and Huberman's (1994) suggestion of conducting case analysis through data timeordered visual displays of critical incidents. Once the chronologies were built, we crosschecked each one individually across key informants to enhance their validity and reliability. Altogether, these five chronologies comprised Nutresa's CPA case history.

Next, we used these five chronologies to conduct within and across host-market analysis to identify Nutresa's CPA choices. Within each chronology, we focused our analysis on the political tactics that Nutresa deployed to uncover the political strategies, approaches to CPA, and options that its senior management chose in each host market. Then, across host markets, we contrasted similarities and differences. Finally, we compared our data with extant literature. We unexpectedly uncovered that, throughout the timeframe of this study, Nutresa's senior management had deliberately chosen to deploy only one approach to CPA in each host market. In particular, Nutresa's senior management had chosen to deploy an engaged approach to CPA in the United States and Costa Rica to exercise the option of voice by engaging with these host governments. In contrast, in Venezuela, Ecuador, and Nicaragua, Nutresa's senior management had deliberately chosen to deploy a non-engaged approach to CPA to exercise the option of loyalty by staying in or entering these host markets, while not engaging with their host governments.

In a second step of the analysis, we centered on how the institutional context of a host market can influence when an MNE's senior management chooses a non-engaged approach to CPA. We categorized Nutresa's host markets into two groups: one group of host markets in which Nutresa had chosen to deploy a non-engaged approach to CPA—comprising Venezuela, Ecuador, and Nicaraguaand a second group of host markets in which Nutresa had chosen to deploy an engaged approach to 
CPA — including the United Stated and Costa Rica. We contrasted similarities and differences among the underlying mechanisms in the institutional context that had influenced the choice of Nutresa's approaches to CPA within and across both groups of host markets. Then, through iterative comparisons between data and theory, a framework emerged to identify and explain the underlying mechanisms in the institutional context of a host market that can influence when an MNE's senior management chooses a non-engaged approach to CPA.

In a third step of the analysis, we focused on how does an MNE deploy a non-engaged approach to CPA. We identified the host markets in which Nutresa had chosen to deploy a nonengaged approach to CPA—Venezuela, Ecuador, and Nicaragua. We contrasted similarities and differences among the non-engaged political tactics deployed by Nutresa in each of these host markets. Finally, we compared these non-engaged political tactics with extant literature to build, from empirical insight, a taxonomy of legal non-engaged political strategies that details how a non-engaged approach to CPA can be deployed to stay in or enter host markets.

\section{Insert Figure 1 Here}

Overall, our data analysis steps involved identifying initial concepts in the data and grouping them into categories or first-order concepts using informants' terms. Next, using axial coding to compare similarities and differences in search of relationships between and among these categories to guide their assembling into second-order themes. Finally, gathering similar second-order themes into aggregate dimensions to build the basis of the framework and taxonomy that emerged (Gioia, Corley, and Hamilton, 2012). This process required using NVivo $9 \circledR$ software to enable intimate and iterative comparisons between theory and data, until reaching theoretical saturation - that is, a close match between theory and data (Gioia et al., 2012; Langley and Abdallah, 2011). A final data structure illustrated in Figure 1, summarizes how we progressed from raw data to second-order themes and aggregate dimensions in each of our data analysis steps.

\section{FINDINGS}

Based on the data structure in Figure 1 and as illustrated in Figure 2, there are four main dimensions to the framework that emerged from the case of Nutresa to explain how the institutional context of a host market can influence when and how an MNE chooses and deploys a non-engaged approach to CPA: 
(1) political strategies, (2) approaches to CPA, (3) options in host markets, and (4) perceived hostcountry political risk. We explain how these dimensions and their themes emerged and relate.

\section{Insert Figure 2 Here}

\section{Political strategies, approaches to CPA, and options in host markets}

The dominant view in extant literature is that MNEs aim to exert influence over host-country public policy in ways favorable to their corporate interests (Hillman et al., 2004). To do so, they choose an engaged approach to CPA that implies staying in or entering a host market to exercise the option of voice (Hirschman, 1970) and deploy any combination of Hillman and Hitt's (1999) engaged political strategies. In keeping with this view, we observed that in the United States, first and second level informants within Nutresa explained that this MNE's senior and general managers used corporate presentations to lobby host-government authorities to make viable and successful Nutresa's acquisition of Abimar Foods. Nutresa's CEO disclosed that their aim in exerting influence over hostgovernment authorities was to become an accepted acquirer of Abimar Foods and access the financial aid that was offered to attract private investors. Through effective lobbying, Nutresa acquired Abimar Foods and gained the financial aid. In Costa Rica, first and second level informants within Nutresa explained that their operations were highly visible. This visibility translated into invitations from Costa Rican political parties for Nutresa to donate funds to their political campaigns. In response, documents validated that Nutresa provided equitable financial contributions to the most representative parties in the country. In addition, Nutresa participated in industry and trade associations in which its voice and stands were communicated to the Costa Rican government through collective lobby by representatives from these associations. Overall, Nutresa's political tactics in the United States and Costa Rica aimed to exert influence over these host-countries' public policy by engaging with their host governments. In accordance with Hillman and Hitt (1999), Nutresa's engaged political tactics indicate that this MNE deployed the strategy of information in the United States and the strategies of financial incentive and information in Costa Rica. To deploy these engaged political strategies, Nutresa chose an engaged approach to CPA that implied staying in or entering these host markets to exercise the option of voice (Hirschman, 1970; Rodriguez et al., 2006). 
Alternatively, neo-institutional theory suggests that MNEs can choose a non-engaged approach to CPA that can have the aim of avoiding or passively conforming to host-country public policy through the non-engaged political strategies of avoidance or acquiescence (Oliver, 1991; Scott, 2014). However, the findings from this study show a different view. To stay in Venezuela and Ecuador and enter Nicaragua, Nutresa chose to deploy a non-engaged approach to CPA through nonengaged political strategies that enabled this MNE to actively adapt rather than to passively conform to these host-countries' public policy. To deploy this approach, Nutresa's non-engaged political tactics show that this MNE used four legal non-engaged political strategies ${ }^{1}$, from which two resonate with the acquiescence or compliance and anticipatory strategies that have been theoretically conceptualized in prior literature (Boddewyn and Brewer, 1994; Oliver, 1991; Oliver and Holzinger, 2008).

Given that extant research focuses on firms' engaging with government, Nutresa's distinct CPA choices in its primary host markets lead us to ask: Why does an MNE's senior management chooses to stay in or enter a host market by deploying a non-engaged over an engaged approach to CPA? Our data triangulation shows that Nutresa deliberately chose a non-engaged approach to CPA to stay in Venezuela and Ecuador and enter Nicaragua, because its senior management viewed that engaging with these host governments could increase Nutresa's visibility and risk exposure. Prior research suggests that MNEs may need to consider flying under the radar because engaging with host governments can increase their visibility and risk exposure (Puck et al., 2013). For example, Nutresa's senior managers explained that being visible in these host markets could motivate increases in operational costs, discriminatory policies, corruption requests, or expropriation. Indeed, research shows that host governments can use the power of legitimate coercion or the ability to exercise authority over firms in different ways (DiMaggio and Powell, 1983; Henisz and Zelner, 2010). Consequently, one of the consistent messages relayed by informants was that Nutresa never engaged with these host governments to try to exert influence over their public policy. As the CEO explained:

'Consciously, we decided that we should evade lobbying because of several reasons. One aspect we discussed at that time was that lobbying in these host markets would take us to scenes where we would be asked to engage in acts of corruption. Another aspect was that

\footnotetext{
${ }^{1}$ Nutresa's non-engaged political tactics and strategies are explained in detail in a following section titled non-engaged political tactics and strategies to stay in or enter host markets.
} 
lobbying could make us more visible, and visibility, could increase our chances of suffering discriminatory measures.'

'We decided not to influence or participate in these host governments. We wanted to stay under their radar.'

Nutresa's senior managers explained that in Venezuela, Ecuador, and Nicaragua they discarded the alternative choice of a non-engaged approach to CPA that involved leaving or not entering these host markets through the option to exit. The reason why Nutresa discarded this alternative was that, in accordance with its long-term international strategy, these were all natural and strategic host markets where Nutresa aimed to sustain or start operations. Being loyal to its international strategy, Nutresa chose not to avoid but, rather, to actively adapt to these host-countries' public policy. Likewise, Hirschman (1970) claims that where there is loyalty, the option to exit may be reduced. As one of Nutresa's VPs explained:

'We decided to stick to our plans by actively working on finding ways to continue or start operations in Venezuela, Ecuador, and Nicaragua, instead of closing operations or delaying our entrance.'

\section{The influence of perceived host-country political risk on CPA}

The choice of a non-engaged approach to CPA is perceived in extant research as caused by, the nonnecessity of engaging due to the favorability of government policy toward the interests of the firm; restrictive regulatory conditions that impede a firm from participating in government affairs; or a firm's inability to engage based on its relative lack of political resources and capabilities (Boddewyn and Brewer, 1994; Bonardi et al., 2006; Holburn and Zelner, 2010). In contrast, our data show that Nutresa's choice to deploy a non-engaged approach to CPA in some host markets, was not caused by any of these antecedents. Senior managers clarified that in all primary host markets Nutresa had identified opportunities to improve the favorability of their host governments' public policy. Concerning regulatory constraints, archival data validated that in all primary host markets, lobbying or information exchange, financial contributions, and constituency-building, were legal activities. Also, informants from all organizational levels within Nutresa and documents evidenced that this MNE had sufficient financial, human, organizational, and physical resources to enable its choice and deployment of an engaged approach to CPA in host markets. Moreover, concerning Nutresa's political capabilities, senior managers and the knowledge management team explained that at the start of the timeframe of 
this study, based on previous experience, Nutresa had substantially developed the capability to engage with host governments to exert influence over their public policy.

From a neo-institutional perspective, an MNE is more likely to choose a non-engaged approach to CPA, involving avoiding or passively conforming to institutional pressures, when the institutional context offers high levels of environmental uncertainty (Oliver, 1991). In contrast, we observed that Nutresa's senior management's choice of a non-engaged approach to CPA, involved actively adapting rather than passively conforming to institutional pressures. However, in line with a neo-institutional perspective, Nutresa's senior managers' choice of a non-engaged approach to CPA was influenced by their perception of host-country political risk. As one VP explained:

'The political risk that we perceived to be challenging our operations in each of these host markets, was critical to our decisions on how to manage our relations with their host governments.'

Nonetheless, despite host-country political risk relates to the notion of environmental uncertainty, perceived host-country political risk as antecedent of the choice of a non-engaged approach to CPA in host markets, has not been addressed through empirical work in prior research (Lux et al., 2011).

Our data show that senior managers defined their perceived host-country political risk as 'the perceived possibility of having policies frequently or discriminatorily changed to disrupt business and/or the possibility of suffering an expropriation by the host government.' Previous research by Henisz and Zelner (2010) and Kobrin (1981) supports the notion that political risk involves both potential policy changes and potential expropriation. Senior managers emphasized that the different levels of their perceived host-country political risk explained their CPA choices in host markets. Through average ratings of their own perceived host-country political risk, we found that in the United States and Costa Rica they had perceived low host-country political risk (see Table 3, fourth column) that had influenced their choice of an engaged approach to CPA to exercise the option of voice. These ideas lead to the following proposition:

Proposition 1a. The lower the level of an MNE's senior management's perceived host-country political risk, the more likely they will choose an engaged approach to CPA to exercise the option of voice.

\section{Insert Table 3 Here}


In contrast, in Venezuela, Ecuador, and Nicaragua senior managers had perceived high hostcountry political risk (see Table 3, fourth column) that had influenced their choice of a non-engaged approach to CPA. In these three host markets, senior managers expected that an engaged approach to CPA could increase Nutresa's visibility and risk exposure, as suggested by prior research (Puck et al., 2013). While on the contrary, senior managers explained that being visible in the United States and Costa Rica could involve a lower risk exposure and even confer performance advantages (see Figure 3). It is worth noting that in Venezuela, Ecuador, and Nicaragua, Nutresa's choice of a non-engaged approach to CPA implied staying in or entering these host markets to exercise the option of loyalty. Senior managers highlighted that if Nutresa had lacked clarity in its decision of being loyal to its international strategy, they could have likely chosen a non-engaged approach to CPA in these host markets to exercise the option to exit. We summarize these ideas in the following proposition:

Proposition $1 \mathrm{~b}$. The higher the level of an MNE's senior management's perceived hostcountry political risk, the more likely they will choose a non-engaged approach to CPA to exercise the option of loyalty or the option to exit.

\section{Insert Figure 3 Here}

In addition, a key insight is that the level of Nutresa's senior management's perceived hostcountry political risk that influenced its CPA choices in host markets, was not only based on risk arising from host-country political institutions, but also on risk emanating from the distance between Nutresa's home and host-government relations. Few studies discuss the influence of home and hostgovernment relations on MNE CPA choices in host markets (Blumentritt, 2003; Blumentritt and Nigh, 2002). As one VP explained:

'We not only perceive a host-country's political risk as a reflection of its institutions. Also, the relations of our Colombian home government with the host government are critical.'

In the case of Nutresa, the risk arising from host-country political institutions was explained by informants through the high or low amounts of checks and balances that constrained a hostgovernment's ability to change existing policies to affect businesses. Prior research has also related the checks and balances of political institutions with the level of political risk in a country (Henisz, 2000; Stevens et al., 2016). As a senior manager explained:

'Institutions in Venezuela, Ecuador, and Nicaragua lack a high amount of checks and balances to restrict these host governments from quickly changing policies. Therefore, 
institutions in these host markets set the scene for political risk to be high. The United States and Costa Rica are different; they have more institutional controls that tend to generate lower political risk.'

We observed that the risk arising from host-country political institutions was assessed by informants through public political risk ratings (see Table 3, second column). Unexpectedly, informants also included the distance between home and host-government relations in their assessments of the level of political risk that they perceived in a host market. Previous research suggests that including the distance between an MNE's home and host-government relations, can provide a more realistic view to the MNE of the level of political risk that it can confront in a host market (Blumentritt and Nigh, 2002; De Villa, Rajwani, and Lawton, 2015; Ghemawat, 2001). Senior managers claimed that the distance in relations between Nutresa's Colombian home and its host governments had been critical in shaping their final perceptions of each host-country's political risk. This distance was described by informants as high or low, according to the level of differences in the political stances between governments. They explained that political relations between Colombia's government and the host governments of Venezuela, Ecuador, and Nicaragua had been distant during more than a decade due to different reasons. Colombia's political relations with Ecuador and Venezuela had mainly suffered frictions due to their differing political stances towards their understandings of democracy. Moreover, spillover effects from drug trafficking and illegal armed groups remained potential sources of friction in Colombia's relations with these two countries (IHS Global Insight, 2012). With Nicaragua, differences in political stances towards their understandings of democracy were accompanied by a territorial dispute over San Andres, Providencia, Santa Catalina, and other territories, that has for decades affected the political relations between both countries. Thus, senior managers explained that the distance in relations between Nutresa's Colombian home government and these three host governments was high. As they described:

'Venezuela used to be Nutresa's most profitable market. When President Chavez came into power, he intended Colombia to unite with Venezuela in expanding its socialist project. Colombia's former President Uribe resisted to promote Venezuela's political regime. Consequently, the differing political stances between Venezuela and Colombia have since then distanced these governments by nurturing anti-Colombian feelings in Venezuela and the persecution of Colombian firms in Venezuela on behalf of this host government. Persecution of Colombian firms has involved designing policies to disrupt their business operations and expropriation.' 
'The Ecuadorian government supports Venezuela's political regime. Consequently, again differing political stances between Ecuador and Colombia have distanced these governments. Moreover, the Colombian government was accused by the Ecuadorian government of a territorial intrusion when the Colombian army killed a guerrilla leader, Raul Reyes, in Ecuador. These political differences and frictions have translated into anti-Colombian feelings that have not triggered expropriations but the implementation of policies designed by the Ecuadorian government to discriminatorily interfere in the operations of Colombian firms in Ecuador.'

'With Nicaragua, Colombia has a distant relation mainly because of a territorial dispute over San Andres, Providencia, Santa Catalina, and other territories. This dispute has generated the imposition of a sovereignty tax on Colombian imports by the Nicaraguan government. This tax significantly deteriorated our conditions to do business with Nicaragua from Colombia.

Besides, this country also supports the expansion of Venezuela's socialist project and is not content with Colombia's differing political stance.'

It is worth noting that senior managers claimed that despite the level of risk arising from hostcountry political institutions, when the distance between Nutresa's home and host-government relations was high, this increased their level of perceived host-country political risk. As a VP claimed:

'If the Colombian government and a host government have distant relations, this is likely to increase political risk for our host-market operations.'

These ideas lead us to the following proposition:

Proposition 2a. High distance between an MNE's home and host-government relations is likely to increase the level of perceived host-country political risk that influences an MNE's CPA choices.

In contrast, Colombia's government and the host governments of Costa Rica and the United States had closer political relations. On the one hand, Costa Rica shared with Colombia similar understandings of democracy that enabled both countries to be recognized as having some of the strongest democracies in Latin America (Brenes and Carneiro, 2013; IHS Global Insight, 2012). On the other hand, Colombia had traditionally been recognized as an ally of the United States in the Latin American region. Cooperation between these two countries had fostered collaboration in fighting drug trafficking and financial aid for Colombia. While, opposingly Venezuela, Ecuador, and Nicaragua have developed over the last decade a stronger discourse against 'the Yankee imperialism' (Vassolo, De Castro, and Gomez-Mejia, 2011). Senior managers explained that the aforementioned conditions enabled a low distance in relations between Nutresa's Colombian home government and the host governments of Costa Rica and the United States. As two VPs described:

'Colombia and Costa Rica have close political relations that have enabled increasing trade and investment between the two countries. This has motivated Nutresa to do business in Costa 
Rica and to engage with the Costa Rican government. In fact, for Nutresa, Costa Rica has become a strategic location from which to competitively supply a host market such as Nicaragua - where distant relations with Colombia impede Nutresa to have direct operations.'

'Colombia has traditionally been recognized as a close ally of the United States in the Latin American region, and these two countries have been characterized by a collaborative relationship. Close government relations have been an incentive for Nutresa to have operations in the United States and to aim to gain benefits by engaging with this government.'

Senior managers explained that despite the level of risk arising from host-country political institutions, when the distance between Nutresa's home and host-government relations was low, this decreased their level of perceived host-country political risk. As a VP explained:

'We have experienced that when the Colombian government and a host government have close relations, this can mitigate the political risk that we face in that host market.'

This leads us to the following proposition:

Proposition 2b. Low distance between an MNE's home and host-government relations is likely to reduce the level of perceived host-country political risk that influences an MNE's CPA choices.

Table 3 summarizes how the distance between Nutresa's home and host-government relations moderated the influence of Nutresa's senior management's perceived host-country political risk on its CPA choices in host markets. Prior research suggests that in a host country, MNEs from different home countries, may expect to be treated differently by the host government based upon their home and host-government relations (Blumentritt, 2003; Blumentritt and Nigh, 2002; Ghemawat, 2001). This may explain why our data show that the distance between an MNE's home and host-government relations can influence MNE CPA choices in host markets through senior managers' perception of host-country political risk.

Finally, prior research has identified that there can be differences among CPA choices as per firms' foreign versus domestic ownership (Getz, 1996; Hillman et al., 2004). However, in Venezuela, Ecuador, and Nicaragua, we observed no differences in the CPA choices of firms by ownership, whereas we noted differences by their level of distance with these host or local governments. In the case of foreign MNEs, high distance between home and host-government relations was common among those that chose to stay in or enter these host markets through a non-engaged approach to CPA. Also, domestic firms or MNEs whose owners were distant and not perceived as allies of the local 
government, frequently became political targets and, in most cases, deployed a non-engaged approach to CPA to stay in these markets. In contrast, foreign MNEs with low distance between their home and host-government relations and local firms or MNEs whose owners were close allies of the local government, generally chose an engaged approach to CPA.

\section{Non-engaged political tactics and strategies to stay in or enter host markets}

As extant research has underexplored how MNEs deploy a non-engaged approach to CPA to stay in or enter host markets (Hillman et al., 2004; Oliver 1991), we detail the non-engaged political tactics that composed the four legal non-engaged political strategies used by Nutresa to deploy this approach. It is worth emphasizing that in Venezuela, Ecuador, and Nicaragua, a triangulation of our data sources showed that although some of Nutresa's non-engaged political tactics considered customers or competitors, all were triggered by and designed exclusively to address institutional conditions within the non-market environment, rather than, the market environment. Hence, Nutresa's non-engaged political tactics were non-market responses. However, market components were integrated with nonmarket components to effectively execute a non-engaged approach to CPA. This resonates with Baron's (1995) assertion that the integration of market and non-market strategies is necessary for effectiveness. As a VP explained:

'In Venezuela, Ecuador, and Nicaragua, we had to develop healthier products for customers to comply with government demands, monitor our prices against those of competitors to assure we were not the most expensive offer that could be accused of speculation, among many others. These actions were taken by Nutresa not to be in a more competitive position in these host markets but, rather, to actively adapt to their changing rules of the game in order to be able to sustain or start our operations.'

Based on the data structure in Figure 1, Nutresa's first group of non-engaged political tactics in Venezuela, Ecuador, and Nicaragua included completely evading influencing these host governments because engaging to exert influence was perceived as not being effective or as increasing Nutresa's visibility and risk exposure. Instead, informants from all organizational levels within Nutresa claimed that this MNE pursued a neutral political stance by not assuming any political position. Further, senior managers explained that they focused on sustaining clear internal communications that centered on the MNE's operations rather than on political stances. Also, General Managers of the operations in Venezuela and Ecuador revealed that Nutresa deployed locals to 
represent this MNE in dealings with host governments, other political actors, and customers to ensure business negotiations and operations were not disrupted by rising anti-foreign feelings toward Colombians and Colombian MNEs. Archival data and informants outside of Nutresa validated that these anti-foreign feelings arose largely from the high distance between Nutresa's home and these host-governments' relations. Particularly in Venezuela, all data sources showed that Nutresa adopted a low public profile by not becoming a market leader but more of a market follower, via pricing its products moderately in consumer markets, because the Venezuelan government often pursued and sanctioned firms that offered the highest prices. In Venezuela, the CEO explained that Nutresa also decided, as a matter of corporate policy, to avoid the media. Senior managers widely believed that comments made by any of Nutresa's employees could potentially be used to portray this MNE as adopting a political stance that could increase its chances of becoming a political target.

Altogether, this group of non-engaged political tactics constitute the first non-engaged political strategy in our taxonomy: the low-visibility strategy, that ensures a minimal degree of general attention from political and social actors. This strategy details how MNE's can deploy Puck and colleagues' (2013) suggestion of flying under the radar of host governments. It aims to allow MNEs to minimize their public visibility and risk exposure, by not engaging with host governments, thereby reducing the likelihood of being the target of discriminatory policies or expropriation. The lowvisibility strategy targets host governments, the MNE's employees, customers, and the media.

A second group of non-engaged political tactics used by Nutresa included never to engage in, or tolerate acts of corruption as a matter of corporate policy. As the CEO explained:

'Our interest is promoting our operations within the legal framework by avoiding corruption.' Instead, Nutresa's non-engaged approach to CPA involved rapidly complying with public policy. Second level informants explained that they worked on developing tools to ensure Nutresa's operations rapidly complied with public policy and an adequate management of external inspections. For example, the General Managers of the distribution and production operations in Venezuela designed checklists to guide their operations in strict and rapid compliance with fast-changing public policies. Also, they created protocols to train employees on every step involved in the management of 
inspections by the host government or any institution overseeing corporate regulatory compliance.

These General Managers in Venezuela explained:

'I started to develop a checklist to guide our operations after being sanctioned with the temporary closure of our site for three days because of a minor non-compliance triggered by the absence of required documentation. After this event, I had to design a tool that would guarantee that the occurrence of a non-compliance would never interrupt operations again.'

'We created a protocols system that has helped us train our employees on how to receive inspections in the most effective way possible to not give any easy reasons for the Venezuelan government to affect our operations or expropriate our site.'

Further, in Venezuela, General Managers and documents validated that Nutresa verified that it complied with paying what were considered by the host government as just prices to suppliers. This practice ensured that Nutresa would not be penalized due to what were referred to as unfair pricing policies. In addition, in all three host markets Nutresa devoted significant efforts to ensure that not only its operations, but also its products were compliant with public policy, as it regularly did in any market. However, in Venezuela, Ecuador, and Nicaragua, Nutresa was extra careful to rapidly comply because these host governments frequently changed the rules of the game and quickly searched for non-complying firms to impose sanctions. For instance, Nutresa quickly modified its product labels in Venezuela to comply with the newly passed law no. 39.658, ostensibly aimed at 'the defense of the people for their access to goods and services' and in practice, used to facilitate the state to expropriate the provision of goods and services considered vital to the public welfare. Moreover, Nutresa also modified its organizational structure and processes to rapidly comply with changing public policy, particularly in Ecuador and Venezuela. For example, in Ecuador, in a few days it directly hired around 500 employees to rapidly comply with Constitutional Mandate no. 8 that prohibited outsourcing, and in Venezuela, it rapidly modified its process for buying U.S. dollars to meet fast-changing regulations.

Overall, this second group of non-engaged political tactics used by Nutresa constitute a distinct non-engaged political strategy in our taxonomy: the rapid-compliance strategy, that entails high speed actions to obey the rules. This strategy resonates with the strategies of acquiescence or compliance that have been theoretically conceptualized in prior literature as involving the tactics of passively conforming to institutional pressures and complying with host-country public policy without aiming to shape or modify its contents (Boddewyn and Brewer, 1994; Oliver, 1991). However, the 
main difference between the strategies of acquiescence or compliance and the rapid-compliance strategy is the speed of compliance. We observed that to stay in or enter a host market of high political risk, MNEs require not only to comply, but to do so rapidly and completely to avoid sanctions, closure, or even expropriation. Prior research suggests that having approval from host governments and legal bodies by rapidly complying is useful to MNEs in terms of enhancing their likelihood of survival through legitimacy (DiMaggio, 1988; DiMaggio and Powell, 1983; Meyer and Rowman, 1977). Note that MNEs attempt to comply in all markets. Particularly, Nutresa complied in all of its primary host markets, including the United States and Costa Rica where it chose an engaged approach to CPA. However, MNEs in host markets where senior managers perceive high host-country political risk, as the case of Nutresa suggests, focus intensively on rapidly complying with fast-changing public policies. The reason why is because non-compliances are frequently used by host governments as rationales to disrupt MNE operations or expropriate firm assets. Thus, the rapid-compliance strategy is targeted at host governments or institutions that verify and police corporate regulatory compliance.

As part of a third group of non-engaged political tactics, second and third level informants within Nutresa explained that, in other cases, this MNE modified its organizational structure and processes not to rapidly comply with public policy, but to efficiently sustain or start competitive operations. For instance, Nutresa created within its organizational structure new individual committees that studied and made decisions about operations in Venezuela, Ecuador, and Nicaragua to ensure that these host-countries' fast-changing rules were confronted through fast decision-making that aligned and incorporated headquarters, host-country managers, and staff. In addition, to supply Venezuela and Ecuador, Logistics Managers explained that Nutresa modified its logistics processes to ensure that products arrived safely at their destination despite political tensions. This approach translated into the definition of numerous new alternative routes and agreements with intermediaries. First level informants showed that Nutresa also worked on developing new ways to supply these restricted host markets by developing alternative production origins in countries from which products could be competitively imported. For example, a VP explained that Nutresa invested in operations in Peru to supply Venezuela and Ecuador. Likewise, Nutresa invested in operations in Costa Rica, from which it could competitively start operations in Nicaragua. As a VP described: 
'When we could not continuously supply Venezuela through our production operations in Colombia due to commercial restrictions imposed as a result of political differences, we invested in developing other production operations from where we could competitively supply this host market. Peru became the origin from where we supplied Venezuela, and then, Ecuador. Also, Costa Rica became the origin from where we started to supply Nicaragua.'

In Venezuela, General Managers explained that Nutresa also reconfigured the origin of some of its inputs by substituting imports for local production to appear as a local value-adding MNE and increase its social support. Prior research explains that social support is important to MNEs as it can influence their viability (Bansal and Roth, 2000; Baum and Oliver, 1991; Deephouse, 1996; Suchman, 1995). Further, the CEO and archival data disclosed that Nutresa changed Colombia as the country of origin in the legal structure of an investment in Venezuela to diminish the potential loss caused by an eventual expropriation. Nutresa made this modification because Costa Rica, the new country of origin for the investment, had closer political relations and an expropriation agreement with Venezuela. Although this agreement does not prevent expropriation, it guarantees a World Bank assurance that a just price is paid to the investor in the case of an expropriation. This agreement shows that a host government can treat the same operation differently due to its country of origin or home and hostgovernment relations (Blumenttrit, 2003; Blumenttrit and Nigh, 2002).

Moreover, General Managers and staff in Venezuela reported that Nutresa acquired physical resources to overcome or manage challenging host-country institutional conditions. For example, in Venezuela, it acquired two energy plants to access energy when the government decided to interrupt electricity services. Also, Nutresa invested in designing replication systems that allowed up-dated access to the information of its operations in Venezuela through computer servers located in the United States to guarantee a safe second copy in the event of an expropriation. This shows that despite the widespread assumption that when there is high political risk MNEs should stop or divest their investments, some investments may be necessary to actively adapt to survive.

Altogether, this third group of non-engaged political tactics constitute a third non-engaged political strategy in our taxonomy: the reconfiguration strategy, that involves re-arranging the MNE's structure and processes for competitiveness. This strategy differs from the rapid-compliance strategy because, although one of its tactics is the same-modifying the MNE's organizational structure and processes - the aims of this tactic differ within each strategy. In the rapid-compliance strategy, 
modifying the MNE's organizational structure and processes is intended to ensure the MNE's rapid compliance with public policy, whereas in the reconfiguration strategy, its aim is to help the MNE to efficiently sustain or start competitive operations. Overall, the aim of the reconfiguration strategy is to align and adapt the MNE's structure and processes to operate competitively in challenging hostcountry institutional conditions. This strategy targets the non-market environment to which the MNE aims to adapt.

A last group of non-engaged political tactics included adopting an anticipatory approach by carefully evaluating future investments to avoid increasing Nutresa's exposure in these host markets. Also, documents and first level interviews within Nutresa showed that in reaction to challenging hostcountry conditions, this MNE re-evaluated and accelerated its international expansion by further penetrating existing markets and more aggressively diversifying its host markets. In doing so, Nutresa conducted a study to determine which strategic markets it should invest in further and which new host markets it should approach to diversify. As the CEO claimed:

'A study helped us re-orient our international expansion according to the challenges we were facing at the time in some of our traditional international markets.'

'We should have done an acquisition in the United States years ago. However, it only happened when we were forced to find ways to mitigate the impact of the conditions we faced in some important host markets like Venezuela and Ecuador.'

In addition, senior managers validated that Nutresa worked on monitoring government relations to assess the level of distance between its home and the host governments of Venezuela, Ecuador, and Nicaragua. It also worked on permanently monitoring these host countries' institutional contexts by using human capital with knowledge such as political analysts, lawyers, and consultants. Nutresa's aim was to identify what policy changes were evolving and to anticipate how to comply with up-coming policies or design ways to react to unpredictable political changes. As an example of anticipation, the General Manager in Ecuador explained that Nutresa had decided to exclude children from publicity in Ecuador since an up-coming law aimed to prohibit their appearance. Similarly, in line with policies pushing for healthier products in Ecuador, Nutresa invested significantly in initiatives to sustain and improve its competitive position by, for example, investing in the creation of improved ingredients that would allow it to offer healthier products demanded by forthcoming 
nutrition policies. Operational staff also explained that Nutresa anticipatorily dedicated efforts to enhance its efficiency by reducing operational costs to overcome increasing operational expenses related to unpredictable changes in these host-countries' policies, such as sudden significant increases to the tax on currency exit in Ecuador. Further, Nutresa focused on monitoring competitors' prices and revising its own prices to assure the best possible profit while avoiding host-government sanctions for speculation. Likewise, Marketing Directors explained that traditional marketing was no longer their focus in these host markets. Instead, their aim to anticipate, enabled them to spend significant time and effort on identifying products that could be supplied competitively and profitably in accordance with changing policies in these host markets to have market presence without financial losses. As one VP explained:

'We want to have presence during difficult times in these host markets as the firms that manage to keep their brands in the minds of consumers will be rewarded when conditions improve.'

Documents also showed that Nutresa conducted an extensive scanning exercise to map and analyze the potential impact of key interest groups on the MNE's operations. General Managers and staff in Venezuela explained that Nutresa monitored these stakeholders' needs and demands and designed ways to build positive community and labor relationships with them. These ways included the introduction of education programs and healthcare initiatives. By establishing and managing these relations, Nutresa increased its chances of being viewed as a local value-adding MNE and of mitigating conflicts arising from the interests of these stakeholders. Prior research claims that firms need to gain acceptability and credibility from these wider stakeholders to obtain their endorsement of legitimacy. Firms exhibiting culturally approved forms and activities, receiving support from normative authorities, and having approval from legal bodies are more likely to survive due to their social fitness or perceived appropriateness, than firms lacking these evaluations (Deephouse et al., 2017; Meyer and Rowman, 1977). Moreover, neo-institutional theorists have demonstrated that legitimacy and social support can exert influence on a firm's viability, independent of its performance, or can even confer performance advantages to firms (Bansal and Roth, 2000; Baum and Oliver, 1991; Deephouse, 1996; Suchman, 1995). In addition, in Nutresa's financial statements, we found that it provisionally set the value of the investments that faced potential expropriation in these host markets 
to mitigate the financial effect of their eventual expropriation. Finally, internal documents disclosed that Nutresa created plans to manage a potential expropriation by outlining the processes to be followed in the occurrence of such an event.

This fourth group of non-engaged political tactics constitute the last non-engaged political strategy in our taxonomy: the anticipation strategy, that implies the prediction of public policy and analysis of interest groups to anticipate responses. This strategy resonates with the anticipatory strategy that has been theoretically conceptualized in prior literature as involving the tactic of anticipating potential changes in public policy to design early compliance mechanisms (Oliver and Holzinger, 2008). However, the findings of this study show that anticipating involves much more than designing early compliance mechanisms. An anticipation strategy aims to gain MNEs a first-mover advantage by anticipating future public policy directions and ways to gain social support to enhance MNEs' legitimacy to survive. This strategy targets the non-market environment and is necessary for MNEs to enable their viability in host markets of high political risk.

\section{Insert Table 4 Here}

Table 4 captures evidence of these four legal non-engaged political strategies in Venezuela, Ecuador, and Nicaragua. Next, Table 5 shows a taxonomy of the four legal non-engaged political strategies that we have described.

\section{Insert Table 5 Here}

Finally, it is worth noting that in Venezuela, Ecuador, and Nicaragua-where Nutresa chose a non-engaged approach to CPA to stay in or enter these host markets by exercising the option of loyalty - our data indicated that the higher Nutresa's senior managers rated their level of perceived host-country political risk, the more Nutresa used all of the four legal non-engaged political strategies to stay in or enter these host markets (see Table 6). This leads us to the following proposition:

Proposition 3. When an MNE's senior management chooses a non-engaged approach to CPA to exercise the option of loyalty, the higher the level of their perceived host-country political risk, the more likely the MNE will increase its use of the low-visibility strategy, rapidcompliance strategy, reconfiguration strategy, and anticipation strategy.

\section{DISCUSSION}

\section{Insert Table 6 Here}


In this study, we analyzed how the institutional context of a host market can influence when and how an MNE's senior management chooses and deploys a non-engaged over an engaged approach to CPA. Despite some scholars arguing that MNEs may need to consider flying under the radar by evading engaged political strategies, because engaging with the host government can increase an MNE's visibility and risk exposure (Puck et al., 2013), the question of when and how an MNE's senior management chooses and deploys a non-engaged approach to CPA is still not well understood. Differing from other studies that discuss the choice of a non-engaged approach to CPA to exercise the option to exit that implies leaving or not entering a host market (Meyer et al., 2009; Rodriguez et al., 2005), we analyzed when and how a non-engaged approach to CPA is chosen and deployed to stay in or enter a host market by exercising the option of loyalty. Overall, the extant literature does not appropriately conceptualize the trade-offs between an engaged and a non-engaged approach to CPA. We explained that when an MNE's senior management decides to stay in or enter a host market of high political risk, managing political risk may not only involve engaging with the host government, or not engaging, and rather, passively conforming to its public policy. We showed how an MNE can create longer term value by actively adapting to host-country public policy through a non-engaged approach to CPA to exercise the option of loyalty.

To better understand the choice and deployment of a non-engaged approach to CPA to exercise the option of loyalty, we conducted a fine-grained analysis of the case of Nutresa. The analysis results in two novel insights. First, we identified that when an MNE's senior management perceives high host-country political risk, it is more likely to choose a non-engaged approach to CPA to exercise the option of loyalty or the option to exit. Further, we explained how the influence of perceived host-country political risk on MNE CPA choices is moderated not only by risk arising from host-country political institutions, but also by risk emanating from the distance between an MNE's home and host-government relations. We identified that a high level of distance between an MNE's home and host-government relations is likely to increase an MNE's senior management's perceived host-country political risk. Consequently, senior management is more likely to choose a non-engaged approach to CPA in the host market. Second, we developed a nuanced conceptualization of approaches to CPA that challenges the notion that not engaging with government only involves avoiding or 
passively conforming to institutional pressures through the strategies of avoidance or acquiescence. We proposed that a non-engaged approach to CPA to stay in or enter host markets of high political risk, requires active adaptation rather than passive conformity. We detailed four legal non-engaged political strategies to deploy this approach: low-visibility, rapid-compliance, reconfiguration, and anticipation.

\section{Theoretical contributions}

From the analysis, we offer several contributions to the extant literature. First, we extend the neoinstitutional theory (DiMaggio, 1988; Oliver, 1991; Scott, 2014) and the antecedents of CPA choices literatures (Hillman et al., 2004; Lux et al., 2011) by theoretically classifying and explaining an MNE's senior management's perceived host-country political risk as an antecedent of MNE CPA choices in host markets. The identification of this antecedent advances our understanding of how institutional factors influence senior managers' perceptions, and thereby, their choice and deployment of an effective approach to CPA. Further, we explained how the level of distance between an MNE's home and host-government relations has a moderating effect on the level of perceived host-country political risk that influences an MNE's CPA choices. Prior research has focused on the influence of the host country on the operations of host MNEs (Cuervo-Cazurra, 2016) or on the influence of the home country by studying corruption (Cuervo-Cazurra, 2006), weak institutions (Cuervo-Cazurra and Genc, 2008), government influence on the economy (García-Canal and Guillén, 2008), and institutional constraints (Holburn and Zelner, 2010). We extend research about the impact of an MNE's home country on its corporate political behavior in various institutional contexts (Blumentritt and Nigh, 2002; Cuervo-Cazurra, 2011), by identifying that an MNE can make different CPA choices in host markets based on the level of distance in relations between its home and host-governments.

Second, we challenge the notion that not engaging with government only involves avoiding or passively conforming to institutional pressures (Oliver, 1991; Scott, 2014). We explained that when an MNE's senior management perceives high host-country political risk, it is more likely to choose a non-engaged approach to CPA that requires either avoiding or actively adapting to host-country public policy. We detailed how actively adapting to host-country public policy can be deployed through four legal non-engaged political strategies. These are: the low-visibility strategy, that explains how MNE's 
can deploy Puck and colleagues' (2013) suggestion of flying under the radar of host governments; the rapid-compliance strategy, that differs by the speed of compliance from the acquiescence or compliance strategies that have been theoretically conceptualized in prior literature; the reconfiguration strategy, that involves re-arranging the MNE's organizational structure and processes for competitiveness; and the anticipation strategy, that differs from the anticipatory strategy that has been theoretically conceptualized in prior research, by showing that beyond designing early compliance mechanisms, its aim is to gain MNEs a first-mover advantage by anticipating future public policy directions and ways to gain social support to enhance legitimacy. Overall, the identification of these four, distinctive and legal non-engaged political strategies, refines our understanding of how a non-engaged approach to CPA to exercise the option of loyalty can be deployed (Boddewyn and Brewer, 1994; Oliver, 1991; Oliver and Holzinger, 2008; Shaffer, 1995). Further, these strategies amplify the portfolio of political strategies available for MNEs, while showing that not engaging with host governments can involve more than avoidance or acquiescence.

\section{Implications for practice}

Our findings are also useful to management practice. First, in raising senior managers' awareness of the importance of assessing how their MNE's home country-particularly the distance between home and host-government relations—can shape their perceived host-country political risk, and influence their CPA choices in host markets. When the distance between their home and host-government relations is low, it can be easy and beneficial for senior managers to choose to engage with the host government. In contrast, when the distance between their home and host-government relations is high, to engage with the host government can increase their MNE's visibility and risk exposure. Under such circumstances, not to engage with the host government can be a choice to consider.

Second, senior managers can also reflect upon their MNE's assessment exercises of hostcountry political risk. We argue that these exercises should not be exclusively based on the study of public political risk ratings. As our findings and prior work (John and Lawton, 2017; Kobrin, 1981) suggest, senior managers within an MNE can provide the best insights on exactly how political risk can affect an MNE's operations in a host market. Hence, assessments of public political risk ratings, by themselves, fall short. This is, in part, because they lack an assessment of the distance between an 
MNE's home and host-government relations, while we observed that this distance matters to MNE CPA choices and can be assessed by senior managers.

Third, the most important implication of this study for management practice is to highlight that MNEs have the option of loyalty. A positive aspect of this option is that MNEs can stay in or enter host markets by minimizing the impact of costs related to changes in host-country public policy and potential host-government interventions. Nevertheless, particularly in an era characterized by the growth in authoritarian regimes and the decline of liberal democracies, the option of loyalty suggests that MNEs can survive, and even be profitable, by flying under the radar of host governments and not being a force for the internationalization of the rule of law and international standards and norms.

Finally, the framework and taxonomy that we offer as walking sticks (Hafsi and Thomas, 2005) can help senior managers understand when and how, to choose and deploy a non-engaged approach to CPA to exercise the option of loyalty. We clarify that our aim is not to advocate the exercise of this option. However, an acceleration of international expansion is increasingly exposing MNEs to different host markets, some of high political risk. Thus, the ability to stay in or enter host markets with high political risk by deploying a non-engaged approach to CPA, can become a source of advantage in managing not only operations in these host markets, but also in managing the diversity of institutional contexts across host markets to internationalize more widely (Cuervo-Cazurra, 2016).

\section{Limitations and future research}

This study has limitations that we hope future research will address. Most significantly, we focus on five host markets in the Americas, which raises the question of whether host markets in other geographies in which MNEs perceive high host-country political risk can show evidence of similar CPA choices and non-engaged political strategies. Therefore, future studies can further explore the combinations of CPA choices and non-engaged political strategies in different locations and across time. Future work can also focus on other industries and use quantitative datasets to broaden our knowledge of MNE CPA choices, and particularly of the choice of a non-engaged approach to CPA. Finally, another interesting future research avenue can be to elaborate on the corporate political behavior of foreign and domestic firms by their level of distance with host or local governments, to expand on the initial insights we gained on their CPA choices. 


\section{ACKNOWLEDGEMENTS}

We appreciate the constructive feedback received from Co-Editor, Alvaro Cuervo-Cazurra, and from our anonymous reviewers. We wish to thank J-P Bonardi, Joseph Clougherty, Jonathan Doh, Constance Helfat, Ann Langley, Jonas Puck, Richard Vanden Bergh, and Richard Whittington for their comments on previous versions of this paper. Our thanks to the audience and conference reviewers at the 2013 SMS Annual Conference in Atlanta, where an earlier version of this paper was nominated for the Best Conference PhD Paper Prize; the 2014 AIB Annual Meeting in Vancouver; the 2014 AIB-LAT Conference in Colombia, where a previous version of this paper won the Best Paper Award; and the 2015 AoM Annual Meeting in Vancouver. We also gratefully acknowledge the access granted by Grupo Nutresa and the financial support provided by COLCIENCIAS and Universidad EAFIT.

\section{REFERENCES}

Aplin, J., \& Hegarty, H. (1980). Political influence: Strategies employed by organizations to impact legislation in business and economic matters. Academy of Management Journal, 23, 438-450.

Bansal, P., \& Roth, K. (2000). Why companies go green: A model of ecological responsiveness. Academy of Management Journal, 43, 717-736.

Baron, D. P. 1995. Integrated strategy: Market and nonmarket components. California Management Review, 37(2), 47-65.

Baum, J. A. C., \& Oliver, C. (1991). Institutional linkages and organizational mortality. Administrative Science Quarterly, 36, 187-218.

Baysinger, B. D. (1984). Domain maintenance as an objective of business political strategies: An extended typology. Academy of Management Review, 9, 248-258.

Blumentritt, T. P. (2003). Foreign subsidiaries' government affairs strategies: The influence of managers and resources. Business \& Society, 42, 202-233.

Blumentritt, T. P., \& Nigh, D. (2002). The integration of subsidiary political activities in multinational corporations. Journal of International Business Studies, 33, 57-77.

Boddewyn, J. J., \& Brewer, T. L. (1994). International-business political behavior: New theoretical directions. Academy of Management Review, 19, 119-143.

Boddewyn, J. J., \& Doh, J. P. (2011). Global strategy and the collaboration of MNEs, NGOs, and governments for the provisioning of collective goods in emerging markets. Global Strategy Journal, 1, 345-361.

Bonardi, J. P., Hillman, A. J., \& Keim, G. D. (2005). The attractiveness of political markets: Implications for firm strategy. Academy of Management Review, 30, 397-413.

Bonardi, J. P., Holburn, G. L. F., \& Vanden Bergh, R. G. (2006). Nonmarket strategy performance: Evidence from U.S. electric utilities. Academy of Management Journal, 49, 1209-1228.

Brenes, E. R., \& Carneiro, J. (2013). Latin American firms competing in the global economy. Journal of Business Research, 67, 831-836.

Cuervo-Cazurra, A. (2006). Who cares about corruption? Journal of International Business Studies, 37, 807-822.

Cuervo-Cazurra, A. (2011). Global strategy and global business environment: The direct and indirect influences of the home country on a firm's global strategy. Global Strategy Journal, 1, 382-386.

Cuervo-Cazurra, A. (2016). Multilatinas as sources of new research insights: The learning and escape drivers of international expansion. Journal of Business Research, 69, 1963-1972.

Cuervo-Cazurra, A., Andersson, U., Brannen, M. Y., Nielsen, B. B., \& Reuber, A. R. (2016). Can I trust your findings? Ruling out alternative explanations in international business research. Journal of International Business Studies, 47, 881-897.

Cuervo-Cazurra, A., \& Genc, M. (2008). Transforming disadvantages into advantages: Developing country MNEs in the least developed countries. Journal of International Business Studies, 39, $957-$ 979.

Deephouse, D. L. (1996). Does isomorphism legitimate? Academy of Management Journal, 39, 10241039.

Deephouse, D. L., Bundy, J., Tost, L. P., \& Suchman, M. C. (2017). Organizational legitimacy: Six key questions. In R. Greenwood, C. Oliver, T. B. Lawrence, \& R. E. Meyer (Eds.), The Sage handbook of organizational institutionalism (pp. 27-54). London: Sage. 
De Villa, M. A., Rajwani, T., \& Lawton, T. (2015). Market entry modes in a multipolar world: Untangling the moderating effect of the political environment. International Business Review, 24, 419-429.

DiMaggio, P. J. (1988). Interest and agency in institutional theory. In L. G. Zucker (Ed.), Institutional patterns and organizations: Culture and environment (pp. 3-21). Cambridge: Ballinger.

DiMaggio, P. J., \& Powell, W. W. (1983). The iron cage revisited: Collective rationality and institutional isomorphism in organizational fields. American Sociological Review, 48, 147-160.

Dinero. (2016, August 18). El Grupo Empresarial Antioqueño es sinónimo del poder paisa. Retrieved from http://www.dinero.com/edicion-impresa/caratula/articulo/el-grupo-empresarial-antioqueno-ysu-reestructuracion-en-sus-negocios/228942.

Edmondson, A. C., \& McManus, S. E. (2007). Methodological fit in management field research. Academy of Management Review, 32, 1155-1179.

Eisenhardt, K. M. (1989). Building theories from case study research. Academy of Management Review, 14, 532-550.

Eisenhardt, K. M., \& Graebner, M. E. (2007). Theory building from cases: Opportunities and challenges. Academy of Management Journal, 50, 25-32.

Evans, D. (1988). Oil PACs and aggressive contribution strategies. The Journal of Politics, 50, 10471056.

García-Canal, E., \& Guillén, M. (2008). Risk and the strategy of foreign location choice in regulated industries. Strategic Management Journal, 29, 1097-1115.

Getz, K. (1993). Selecting corporate political activities. In B. Mitnick (Ed.), Corporate political agency (pp. 152-170). Newbury: Sage.

Getz, K. (1996). Politically active foreign-owned firms in the US: Elephants or chickens? In D. Woodward \& D. Nigh (Eds.), Beyond us and them: Foreign ownership and US competitiveness (pp. 231-253). Columbia: University of South Carolina Press.

Ghemawat, P. (2001). Distance still matters: The hard reality of global expansion. Harvard Business Review, 79(8), 137-147.

Gioia, D. A., Corley, K. G., \& Hamilton, A. L. (2012). Seeking qualitative rigor in inductive research: Notes on the Gioia methodology. Organizational Research Methods, 16, 15-31.

Golden, B. R. (1992). The past is the past-or is it? The use of retrospective accounts as indicators of past strategy. Academy of Management Journal, 35, 848-860.

Grier, K. B., \& Munger, M. C. (1993). Comparing interest group PAC contributions to House and Senate incumbents, 1980-1986. The Journal of Politics, 55, 615-643.

Hafsi, T., \& Thomas, H. (2005). The field of strategy: In search of a walking stick. European Management Journal, 23, 507-519.

Heidenreich, M. (2012). The social embeddedness of multinational companies: A literature review. Socio-Economic Review, 10, 549-579.

Henisz, W. J. (2000). The institutional environment for multinational investment. Journal of Law, Economics, and Organization, 16, 334-364.

Henisz, W. J., \& Zelner, B. A. (2010). The hidden risks in emerging markets. Harvard Business Review, 88(4), 88-95.

Hillman, A. J., \& Hitt, M. A. (1999). Corporate political strategy formulation: A model of approach, participation, and strategy decisions. Academy of Management Review, 24, 825-842.

Hillman, A. J., Keim, G. D., \& Schuler, D. (2004). Corporate political strategies: A review and research agenda. Journal of Management, 30, 837-857.

Hirschman, A. O. (1970). Exit, voice, and loyalty: Responses to decline in firms, organizations, and states. United States: Harvard University Press.

Holburn, G. L. F., \& Zelner, B. (2010). Political capabilities, policy risk, and international investment strategy: Evidence from the global electric power generation industry. Strategic Management Journal, 31, 1290-1315.

Huber, G. P., \& Power, D. J. (1991). Retrospective reports of strategic-level managers: Guidelines for increasing accuracy. Strategic Management Journal, 6, 171-180.

Huff, A. S. (2009). Designing research for publication. Thousand Oaks: Sage Publications.

IHS Global Insight. (2012). Political risk ratings. (accessed 3 March 2012). 
John, A., \& Lawton, T. (2017). International political risk management: Perspectives, approaches and emerging agendas. International Journal of Management Reviews.

Keim, G. D., \& Baysinger, B. D. (1988). The efficacy of business political activity: Competitive considerations in a principal agent context. Journal of Management, 14, 163-180.

Kobrin, S. J. (1981). Political assessment by international firms: Models or methodologies? Journal of Policy Modeling, 3, 251-270.

Kobrin, S. J. (2015). Is a global nonmarket strategy possible? Economic integration in a multipolar world order. Journal of World Business, 50, 262-272.

Kostova, T., Roth, K., \& Dacin, M. T. (2008). Institutional theory in the study of multinational corporations: A critique and new directions. Academy of Management Review, 33, 994-1006.

Langley, A. (1999). Strategies for theorizing from process data. Academy of Management Review, 24, 691-710.

Langley, A., \& Abdallah, C. (2011). Templates and turns in qualitative studies of strategy and management. In D. Bergh \& D. Ketchen (Eds.), Building methodological bridges: Research methodology in strategy and management (pp. 201-235). Bingley: Emerald Group.

Lawton, T., McGuire, S., \& Rajwani, T. (2013). Corporate political activity: A literature review and research agenda. International Journal of Management Reviews, 15, 86-105.

Lux, S., Crook, T. R., \& Woehr, D. J. (2011). Mixing business with politics: A meta-analysis of the antecedents and outcomes of corporate political activity. Journal of Management, 37, 223-247.

Masters, M., \& Keim, G. (1985). Determinants of PAC participation among large corporations. The Journal of Politics, 47, 1158-1173.

Meyer, K. E., Estrin, S., Bhaumik, S. K., \& Peng, M. W. (2009). Institutions, resources, and entry strategies in emerging economies. Strategic Management Journal, 30, 61-80.

Meyer, J. W., \& Rowan, B. (1977). Institutionalized organizations: Formal structure as myth and ceremony. American Journal of Sociology, 83, 340-363.

Meyer, J. W., \& Scott, W. R. (1983). Centralization and the legitimacy problems of local government. In J. W. Meyer \& W. R. Scott (Eds.), Organizational environments: Ritual and rationality (pp.199-215). Sage: Beverly Hills.

Meznar, M., \& Nigh, D. (1995). Buffer or bridge? Environmental and organizational determinants of public affairs strategies in American firms. Academy of Management Journal, 38, 975-996.

Miles, M. B., \& Huberman, A. M. (1994). Qualitative data analysis: An expanded sourcebook. Thousand Oaks: Sage Publications.

Miller, C. C., Cardinal, L. B., \& Glick, W. H. (1997). Retrospective reports in organizational research: A reexamination of recent evidence. Academy of Management Journal, 40, 189-204.

Oberman, W. (1993). Strategy and tactic choice in an institutional resource context. In B. Mitnick (Ed.), Corporate political agency (pp. 301-324). Newbury: Sage.

Oliver, C. (1991). Strategic responses to institutional processes. Academy of Management Review, 16, $145-179$.

Oliver, C., \& Holzinger, I. (2008). The effectiveness of strategic regulatory management: A dynamic capabilities framework. Academy of Management Review, 33, 496-520.

Perrow, C. (1985). Review essay: Overboard with myth and symbols. American Journal of Sociology, 91, 151-155.

Powell, W. W. (1985). The institutionalization of rational organizations. Contemporary Sociology, 14, 564-566.

Puck, J. F., Rogers, H., \& Mohr, A. T. (2013). Flying under the radar: Foreign firm visibility and the efficacy of political strategies in emerging economies. International Business Review, 22, 10211033.

Rodriguez, P., Siegel, D. S., Hillman, A. J., \& Eden, L. (2006). Three lenses on the multinational enterprise: Politics, corruption, and corporate social responsibility. Journal of International Business Studies, 37, 733-746.

Rodriguez, P., Uhlenbruck, K., \& Eden, L. (2005). Government corruption and the entry strategies of multinationals. Academy of Management Review, 30, 383-396.

Schuler, D., \& Rehbein, K. (1997). The filtering role of the firm in corporate political involvement. Business \& Society, 36, 116-139. 
Scott, W. R. (2014). Institutions and organizations: Ideas, interests, and identities (4th ed.). Thousand Oaks: Sage.

Shaffer, B. (1995). Firm-level responses to government regulation: Theoretical and research approaches. Journal of Management, 21, 495-514.

Stevens, C. E., Xie, E., \& Peng, M. W. (2016). Toward a legitimacy-based view of political risk: The case of Google and Yahoo in China. Strategic Management Journal, 37, 945-963.

Streeck, W., \& Schmitter, P. C. (1985). Community, market, states-and associations? The prospective contribution of interest governance to social order. In W. Streeck \& P. C. Schmitter (Eds.), Private interest government: Beyond market and state (pp. 1-29). Beverly Hills: Sage.

Suchman, M. C. (1995). Managing legitimacy: Strategic and institutional approaches. Academy of Management Review, 20, 571-610.

Vassolo, R. S., De Castro, J. O., \& Gomez-Mejia, L. R. (2011). Managing in Latin America: Common issues and a research agenda. Academy of Management Perspectives, 25(4), 22-36.

Vogel, D. (1996). The study of business and politics. California Management Review, 38(3), 146-165.

Weidenbaum, M. (1980). Public policy: No longer a spectator sport for business. Journal of Business Strategy, 1(1), 46-53.

Yin, R. K. (2009). Case study research: Design and methods (4th ed.). California: Sage. 
Table 1 Approaches to CPA and political strategies

\begin{tabular}{|c|c|c|}
\hline & Engaged approach to CPA & Non-engaged approach to CPA \\
\hline Aim & To enable MNEs to influence host-country public policy & To enable MNEs to avoid or conform to host-country public policy \\
\hline Relation with the host-government & Involves engaging with the host-government & Involves evading engagement with the host-government \\
\hline \multirow[t]{4}{*}{ Political strategies } & Information & Avoidance \\
\hline & Financial incentive & Acquiescence or compliance \\
\hline & Constituency-building & Circumvention \\
\hline & & Anticipatory \\
\hline View of compliance & $\begin{array}{l}\text { Involves complying with host-country public policy } \\
\text { while searching to shape or modify its contents in } \\
\text { ways favorable to the MNE's corporate interest }\end{array}$ & $\begin{array}{l}\text { Involves complying with host-country public policy } \\
\text { without aiming to shape or modify its contents }\end{array}$ \\
\hline \multirow[t]{4}{*}{ Other labels } & Public policy shaping (Weidenbaum, 1980) & Passive reaction, positive anticipation (Weidenbaum, 1980) \\
\hline & Bargaining behavior (Boddewyn and Brewer, 1994) & Non-bargaining behavior (Boddewyn and Brewer, 1994) \\
\hline & Political buffering (Blumentritt, 2003; Meznar and Nigh, 1995) & Political bridging (Blumentritt, 2003; Meznar and Nigh, 1995) \\
\hline & Proactive CPA (Hillman et al., 2004) & Reactive CPA (Hillman et al., 2004) \\
\hline
\end{tabular}


Table 2 Description of data

\begin{tabular}{|c|c|c|c|c|}
\hline Data sources & Description & & Number & Total \\
\hline \multirow[t]{15}{*}{ Interviewees } & Within Nutresa & & & \\
\hline & - First level & Board members & 2 & 60 \\
\hline & & CEO & 1 & \\
\hline & & VPs of the business lines with operations in the host markets & 8 & \\
\hline & & $\mathrm{CFO}$ & 1 & \\
\hline & & VP of the General Council & 1 & \\
\hline & - Second level & General Managers of operations in the host markets & 5 & \\
\hline & & International Business Directors & 5 & \\
\hline & & Logistics Managers & 7 & \\
\hline & & Marketing Directors & 7 & \\
\hline & & Coordinators of centralized treasury, auditing, legal assessment, human resources, risk management, innovation, and IT & 10 & \\
\hline & - Operational level & Other business level staff & 10 & \\
\hline & Outsiders & Ex-CEO of a Venezuelan retail chain & 1 & \\
\hline & & President of Colombia's international trade association & 1 & \\
\hline & & Former Colombian Ambassador to Venezuela & 1 & \\
\hline \multirow[t]{3}{*}{ Documents } & Public & Annual reports 1998-2013 & 16 & 44 \\
\hline & Internal & Report about the evolution of the number of employees versus sales in each host market between 1998-2013 & 1 & \\
\hline & & Classified records of the strategic tools developed by Nutresa for its operations in Venezuela between 1998-2013 & 27 & \\
\hline \multirow[t]{2}{*}{ Archives } & Public & Media articles about the events that occurred in each host market between 1998-2013 & 60 & 63 \\
\hline & & Media articles about Nutresa's corporate political activities in each host market between 1998-2013 & 3 & \\
\hline
\end{tabular}




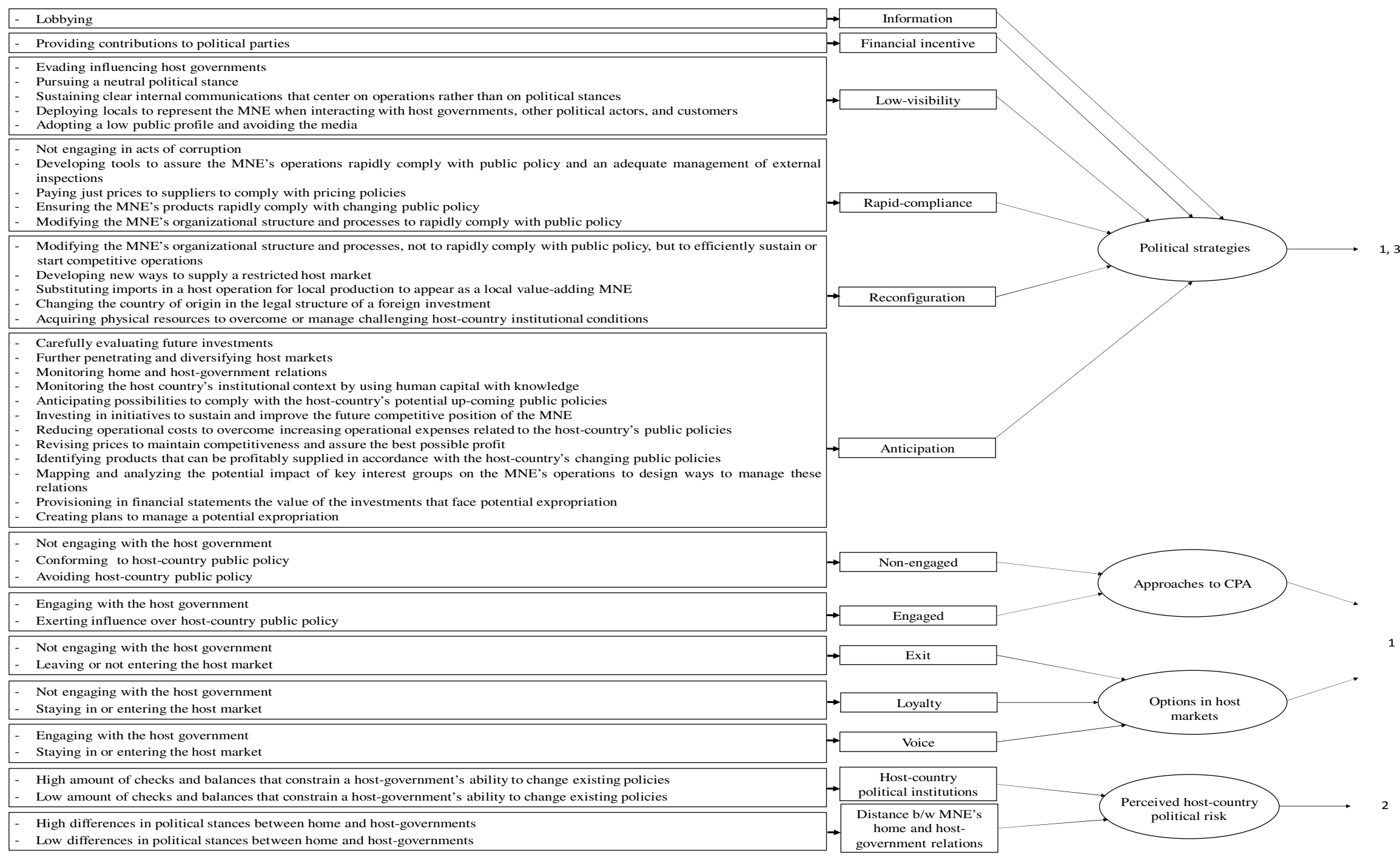

Figure 1 Data structure 


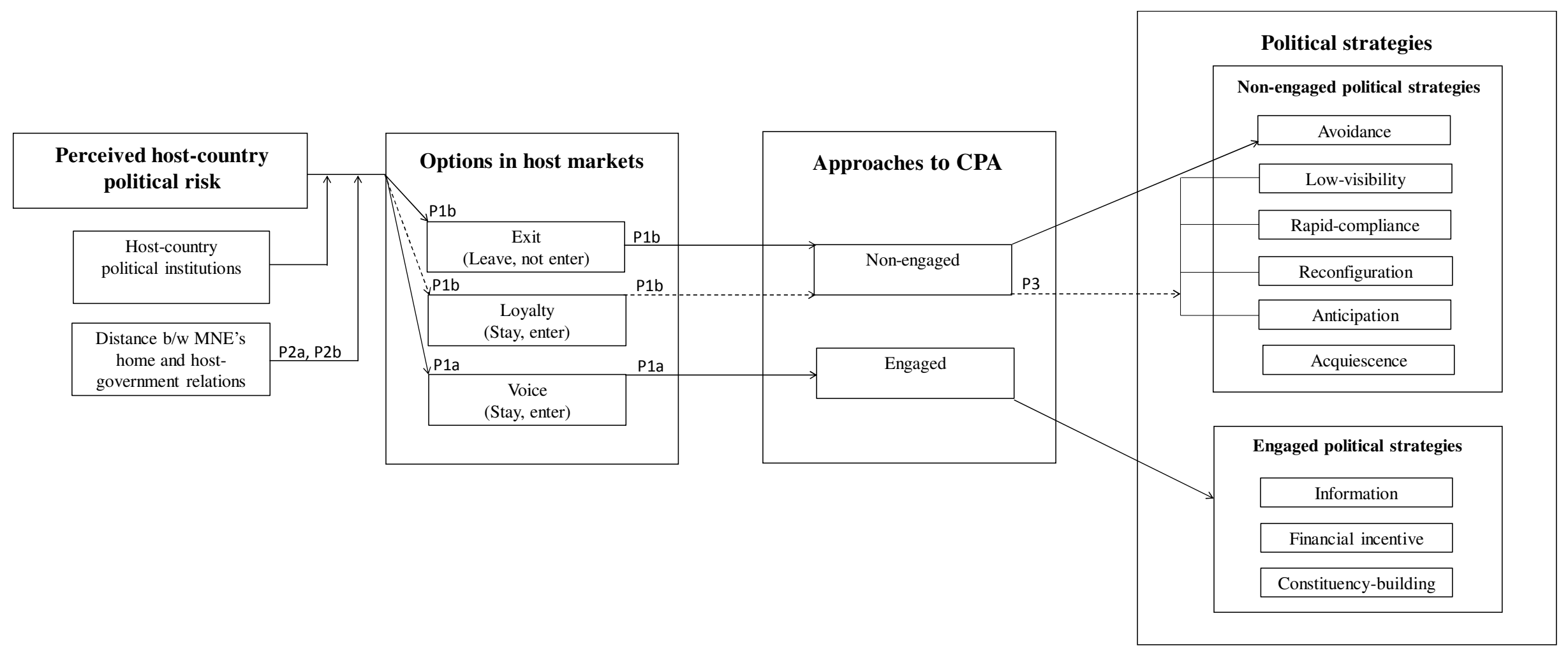

Figure 2 The influence of perceived host-country political risk on MNE CPA choices in host markets 
Table 3 Nutresa's CPA choices in host markets

\begin{tabular}{|c|c|c|c|c|c|c|}
\hline Host markets & $\begin{array}{l}\text { Public } \\
\text { host-country } \\
\text { political risk } \\
\text { ratings* }\end{array}$ & $\begin{array}{l}\text { Distance } b / w \text { Nutresa's } \\
\text { home and host- } \\
\text { government relations }\end{array}$ & $\begin{array}{l}\text { Perceived } \\
\text { host-country } \\
\text { political risk } \\
\text { ratings** } \\
\end{array}$ & $\begin{array}{l}\text { Options in } \\
\text { host markets }\end{array}$ & $\begin{array}{l}\text { Approaches } \\
\text { to CPA }\end{array}$ & Quotes \\
\hline United States & 1.3 & Low & 1 & Voice & Engaged & $\begin{array}{l}\text { 'When Colombia has close relations with a host government, this is ideal for our } \\
\text { business. In such cases, the host government is not that much of a threat to our }\end{array}$ \\
\hline Costa Rica & 2.0 & Low & 1 & Voice & Engaged & $\begin{array}{l}\text { operations. In fact, we can lobby the host government through associations or } \\
\text { even directly. We feel free to express our stands and to design different legal ways } \\
\text { to gain benefits for our own interests.' }[V P]\end{array}$ \\
\hline Venezuela & 4.0 & High & 5 & Loyalty & Non-engaged & $\begin{array}{l}\text { 'When a host government has distant political relations with the Colombian } \\
\text { government-that is our home-government-we find Nutresa can easily become a }\end{array}$ \\
\hline Ecuador & 3.8 & High & 4.4 & Loyalty & Non-engaged & $\begin{array}{l}\text { political target for such host government. In that case, the host government may } \\
\text { frequently aim to disrupt our business to affect our home-government, }\end{array}$ \\
\hline Nicaragua & 3.8 & High & 4 & Loyalty & Non-engaged & $\begin{array}{l}\text { particularly when both governments have substantial political differences. We } \\
\text { don't engage with this type of host governments; we don't want to be visible in } \\
\text { such host markets. Rather, we focus on adapting to the high political risk that they } \\
\text { entail for our operations so that we can do business.' [VP] }\end{array}$ \\
\hline
\end{tabular}

The ratings in this column follow a scale from 1 to 5 , being 1 the lower score and 5 the higher score. A rating of 1, means this country has a strong, well-developed, and effective democracy that ensures a very high level of political stability. Changes of government involve broad policy continuity. A rating of 2, means political institutions are strong. More extreme opposition is generally contained within the political system. Any changes of

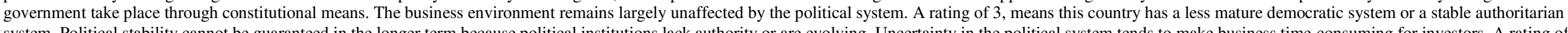

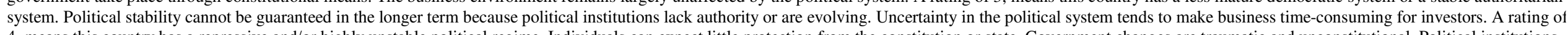

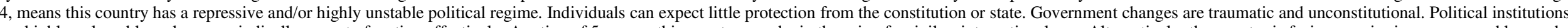

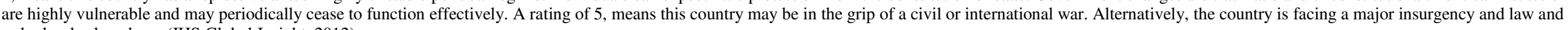
order has broken down (IHS Global Insight, 2012).

** The ratings in this column follow a scale from 1 to 5 , being 1 the lower score and 5 the higher score. Ratings between 1 and 2.5 indicate low host-country political risk while ratings between 3.5 and 5 indicate high hostcountry political risk. 


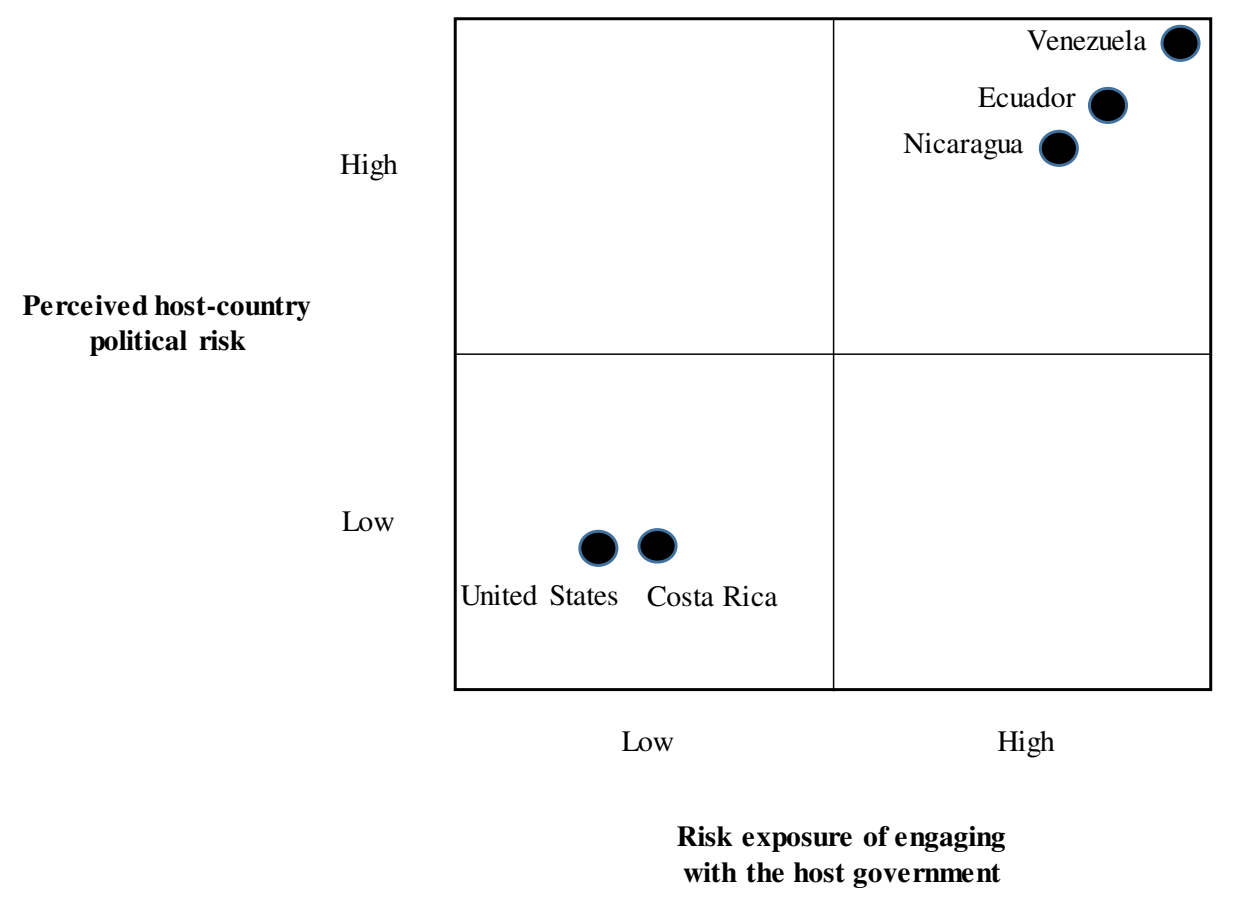

Figure 3 Perceived host-country political risk and risk exposure of engaging with the host government 
Table 4 Evidence of the four legal non-engaged political strategies in each host market

\begin{tabular}{|c|c|c|}
\hline Host markets & $\begin{array}{l}\text { Legal non-engaged } \\
\text { political strategies }\end{array}$ & Quotes \\
\hline \multirow[t]{4}{*}{ Venezuela } & Low-visibility strategy & $\begin{array}{l}\text { *** 'We were politically neutral and adopted a low profile since this host government is scanning to identify 'against the regime' firms to apply } \\
\text { hostile measures against them or even expropriate their sites.' [1001] }\end{array}$ \\
\hline & Rapid-compliance strategy & $\begin{array}{l}\text { *** 'We modified our product labels, kept inventories low, and our prices followed those leading the market to ensure we could not be accused } \\
\text { of price speculation by complying with law } 39.658 \text { in defense of the people for their access to goods and services.' [I007] }\end{array}$ \\
\hline & Reconfiguration strategy & *** 'We modified the legal proprietary structure of the production operation in Venezuela to a different origin: Costa Rica.' [1004] \\
\hline & Anticipation strategy & *** 'We have anticipated our entrance to new host markets in response to difficult conditions in Venezuela.' [I001] \\
\hline \multirow[t]{4}{*}{ Ecuador } & Low-visibility strategy & *** 'We adopted a politically neutral stance, not in favor of any government or party.' [1001] \\
\hline & Rapid-compliance strategy & *** 'We hired our outsourced employees directly to comply with the law that prohibited outsourcing in Ecuador.' [1045] \\
\hline & Reconfiguration strategy & $\begin{array}{l}\text { ** 'Our new production operation in Peru gave us the security of having a second origin of exports through which we could provide products } \\
\text { to Ecuador.' [IO17] }\end{array}$ \\
\hline & Anticipation strategy & ** 'We permanently monitored prices every week and then every day.' [1056] \\
\hline \multirow[t]{4}{*}{ Nicaragua } & Low-visibility strategy & $\begin{array}{l}\text { *** 'We evaded lobbying the Nicaraguan government because we were aware that this would not produce positive outcomes for the firm due } \\
\text { to political differences between the Nicaraguan and our country of origin governments.' [I015] }\end{array}$ \\
\hline & Rapid-compliance strategy & ** 'We incurred in no acts of corruption to operate in Nicaragua.' [1015] \\
\hline & Reconfiguration strategy & $\begin{array}{l}\text { *** 'We bought production operations in a new origin-Costa Rica-. Through these acquisitions we found production operations from which } \\
\text { to competitively supply the Nicaraguan market.' [1001] }\end{array}$ \\
\hline & Anticipation strategy & $\begin{array}{l}\text { *** 'We anticipated market restrictions derived from political differences were not going to change soon, and therefore, we designed alternative } \\
\text { ways to enter Nicaragua.' [1015] }\end{array}$ \\
\hline
\end{tabular}


Table 5 Taxonomy of legal non-engaged political strategies to stay in or enter host markets of high political risk

$\begin{array}{llll}\text { Low-visibility strategy } & \text { Rapid-compliance strategy } & \text { Reconfiguration strategy } & \text { Anticipation strategy }\end{array}$

\begin{tabular}{ll}
\hline Definition & $\begin{array}{l}\text { Minimal degree of general attention from } \\
\text { political and social actors }\end{array}$
\end{tabular}

Aim

Aim to minimize the public visibility and risk exposure of MNEs, by not engaging with host governments, thereby reducin the likelihood of being the target of discriminatory policies or expropriation

Target Host governments, employees, customers, and the media

Tactics - Evading influencing host governments

Evading influencing host governme

- Sustaining clear internal communication that center on operations rather than on political stances

- Deploying locals to represent the MNE when interacting with host governments, other political actors, and customers

- Adopting a low public profile and avoiding the media
Rapid-compliance strategy

High speed actions to obey the rules

Re-arranging the MNE's organizational

structure and processes for competitiveness

Aim to ensure MNEs comply with hostcountries' public policy rapidly and completely to avoid sanctions, closure, or even expropriation

Host governments or institutions that verify and police corporate regulatory compliance

- Not engaging in acts of corruption

Developing tools to assure the MNE's operations rapidly comply with public policy and an adequate management of external inspections

Paying just prices to suppliers to comply with pricing policies

Ensuring the MNE's products rapidly comply with changing public policy

- Modifying the MNE's organizational structure and processes to rapidly comply with public policy
Aim to align and adapt the structure and processes of MNEs to operate competitively in challenging host-country institutional conditions

\section{The non-market environment}

- Modifying the MNE's organizational structure and processes, not to rapidly comply with public policy, but to efficiently sustain or start competitive operations

Developing new ways to supply a restricted host market

- Substituting imports in a host operation for local production to appear as a local valueadding MNE

Changing the country of origin in the legal structure of a foreign investment

- Acquiring physical resources to overcome or manage challenging host-country nstitutional conditions
Prediction of public policy and analysis of interest groups to anticipate responses

Aim to gain MNEs a first mover advantage by anticipating host governments' future public policy directions and ways to gain social support to enhance MNEs' legitimacy to survive

The non-market environment

- Carefully evaluating future investments

- Further penetrating and diversifying host markets - Monitoring home and host-government relations - Monitoring the host country's institutional contex by using human capital with knowledge

- Anticipating possibilities to comply with the hostcountry's potential up-coming public policies

Investing in initiatives to sustain and improve the future competitive position of the MNE

- Reducing operational costs to overcome increasing operational expenses related to the host-country's public policies

- Revising prices to maintain competitiveness and assure the best possible profit

- Identifying products that can be profitably supplied in accordance with the host-country's changing public policies

- Mapping and analyzing the potential impact of key interest groups on the MNE's operations to design ways to manage these relations

- Provisioning in financial statements the value of the investments that face potential expropriation - Creating plans to manage a potential expropriation 
Table 6 Nutresa's perceived host-country political risk and the use of legal non-engaged political strategies

\begin{tabular}{lllllc}
\hline Host markets & $\begin{array}{l}\text { Perceived host-country } \\
\text { political risk ratings* }\end{array}$ & Low-visibility strategy*** & Rapid-compliance strategy & Reconfiguration strategy & Anticipation strategy \\
\hline Venezuela & 5 & 7 & 5 & 13 & 14 \\
Ecuador & 4.4 & 4 & 2 & 3 & 10 \\
Nicaragua & 4 & 1 & 1 & 2 & 1 \\
United States & 1 & 0 & 0 & 0 & 0 \\
Costa Rica & 1 & 0 & 0 & 0 & 0 \\
\hline
\end{tabular}

* The ratings in this column follow a scale from 1 to 5 , being 1 the lower score and 5 the higher score. Ratings between 1 and 2.5 indicate low host-country political risk while ratings between 3.5 and 5 indicate high host-country political risk.

** The numbers in this column and the following columns indicate the frequency of use of each legal non-engaged political strategy in each host market. 